IMF STAFF DISCUSSION NOTE

Revitalizing Securitization for Small and Medium-Sized Enterprises in Europe

Shekhar Aiyar, Ali Al-Eyd, Bergljot Barkbu, and Andreas A. Jobst 
IMF STAFF DISCUSSION NOTE

Revitalizing Securitization for Small and Medium-Sized Enterprises in Europe

Shekhar Aiyar, Ali Al-Eyd, Bergljot Barkbu, and Andreas A. Jobst 
INTERNATIONAL MONETARY FUND

European Department

\title{
Revitalizing Securitization for Small and Medium-Sized Enterprises in Europe
}

Prepared by Shekhar Aiyar, Ali Al-Eyd, Bergljot Barkbu, and Andreas A. Jobst ${ }^{1}$

Authorized for distribution by Mahmood Pradhan

May 2015

\begin{abstract}
DISCLAIMER: This Staff Discussion Note represents the views of the authors and does not necessarily represent IMF views or IMF policy. The views expressed herein should be attributed to the authors and not to the IMF, its Executive Board, or its management. Staff Discussion Notes are published to elicit comments and to further debate.
\end{abstract}

JEL Classification Numbers: $\quad$ E44, O16, G100

Keywords:

Structured finance, financial intermediation, macrofinancial linkages, SME finance saiyar@imf.org, aaleyd@imf.org, bbarkbu@imf.org, and

Authors' E-mail Addresses: ajobst@imf.org

\footnotetext{
${ }^{1}$ Corresponding author. The authors thank Pontus Aberg, Johannes Blankenheim, Rémi Charrier, José M. Garrido, Federico Galizia, Richard Hopkins, Nadège Jassaud, Brad Jones, Kenneth Kang, John Kiff, Helmut Kraemer-Eis, Peter Lindner, Camelia Minoiu, Dermot Monaghan, George Passaris, Jiri Podpiera, Mahmood Pradhan, Petia Topalova, Lev Ratnovski, Nobuyasu Sugimoto, Yan Sun, Murtaza Syed, Srichander Ramaswamy, and staff from the Financial Stability Department of the Deutsche Bundesbank and the German Ministry of Finance for helpful comments and suggestions. Research assistance from Jesse Siminitz is gratefully acknowledged. A preliminary version of this paper was presented at a joint EIB-IMF high-level workshop, "Unlocking SME Financing in Europe and the Role of Capital Markets: SME Securitization and Distressed Assets" October 22-23, 2014, in Brussels.
} 


\section{CONTENTS}

EXECUTIVE SUMMARY .

WHY DEVELOP SME SECURITIZATION? $\underline{5}$

IMPEDIMENTS TO SME SECURITIZATION $\underline{13}$

A. Insufficient Regulatory Differentiation ....................................................................................................

B. Incomplete Market Infrastructure and Obstacles to Cross-Border Investments.................................... 17

POLICIES TO REVITALIZE SME SECURITIZATION .................................................................. 19

A. Ensuring Greater Regulatory Differentiation of High-Quality Securitization (HQS) ............................ 19

B. Strengthening the Infrastructure for SME Securitization ...................................................................... 22

C. Providing Targeted Official Sector Support ..........................................................................................

CONCLUSION

\section{ANNEX}

I. Regulatory Capital Charges for Securitization.....

\section{BOXES}

1. Overview of the European Securitization Market.........................................................................................

2. EU Initiatives to Support SME Securitization ................................................................................................. 11

3. The Impact of Capital Regulation on Banks and Insurance Investment in SME Securitization and Covered Bonds.

4. Summary of Proposed Attributes of High-Quality Securitization and Additional Criteria for SME Loans as Reference Assets. $\underline{21}$

5. The European Central Bank's Asset-Backed Securities Purchase Program

\section{FIGURES}

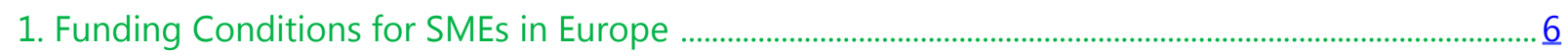

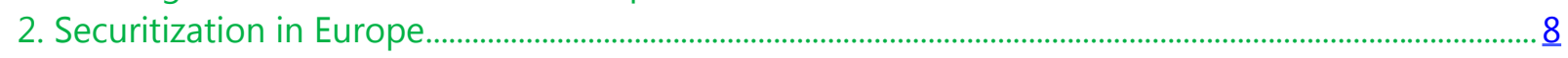

3. European Securitization: Market-Implied Regulatory Capital Charge for Banks and Insurers at Current Market Prices, as of end-December 2014 ........................................................................................... 16 4. Euro Area: Private Sector Credit and Average Recovery Rate on Loans Relative to Changes in NonPerforming Exposure (NPE) after the ECB's Asset Quality Review (AQR)

\section{TABLES}

1. EU Support Initiatives for SME Securitization

A1. Overview Comparison of Regulatory Capital Charges for Credit Exposures and Investment in Securitization (in percent) 


\section{EXECUTIVE SUMMARY}

Small- and medium-sized enterprises (SMEs) account for more than half of business sector output and employment in Europe. Because they are highly dependent on bank finance, however, many SMEs, especially in vulnerable economies, find themselves credit-rationed or facing high borrowing costs in the wake of the recent financial crisis. These structural constraints hamper viable SMEs' ability to invest, thereby undermining the recovery of output and employment. With banks still focused on raising capital and weighed down by impaired assets, the sources of long-term funding for SMEs need to be broadened. This action would alleviate potential credit constraints and make smaller firms more resilient to future shocks to the banking sector.

\section{A well-functioning and liquid securitization market is a promising avenue to enhance the lending capacity of banks and permanently broaden funding options for SMEs while supporting greater integration of European capital markets. However, various impediments} inhibit the further development of the European SME securitization market. The regulatory framework, including liquidity risk standards and capital requirements, does not provide the right incentives for high-quality securitization (HQS). In addition, fragmented national insolvency and debt enforcement regimes and the lack of harmonized credit information across EU countries raise the cost of issuance and limit the investor base. Overcoming these hurdles is essential to revitalizing the market for SME securitization. Moreover, efforts in this direction would also enhance financial stability and help integrate European capital markets. A vibrant SME securitization market would be an important milestone on the road to an eventual Capital Markets Union (CMU).

This discussion note proposes a comprehensive, multi-faceted strategy combining regulatory reforms and infrastructure development with targeted and time-bound official sector support to help revitalize the SME securitization market in Europe. This strategy involves: (1) encouraging greater regulatory differentiation among securities of varying underlying asset quality and structures; (2) developing the right market infrastructure and facilitating cross-border investment through EU frameworks for harmonized credit reporting and insolvency regimes; and (3) enhancing the scope of current EU initiatives for SME finance together with introducing a more nuanced treatment of SME-related collateral for refinancing with the Eurosystem. These measures would be underpinned by a pan-European definition of high-quality securitization (HQS) comprising simple, transparent, and efficient asset structures that can receive preferential regulatory treatment and official-sector support. 


\section{WHY DEVELOP SME SECURITIZATION?}

\section{Ensuring that viable SMEs can finance themselves is essential to supporting the} recovery. Often referred to as the "backbone" of Europe's economy, SMEs constitute the greater share of European output and employment. They account on average for 99 out of every 100 businesses, 2 in every 3 employees and 58 cents of every euro of value added of the business sector (industry, construction, trade and services) in the EU (European Commission 2014a). In some economies, such as Italy, Portugal, and Spain, they account for an even larger share of output and employment (Figure 1). Finding ways to support credit to SMEs is therefore essential to supporting the economic recovery (Kraemer-Eis, Lang, and Gvetadze 2014a). ${ }^{2}$

2. Since the onset of the financial crisis, European SMEs have faced a credit crunch. While the recession induced a reduction in the demand for credit, credit supply to the corporate sector-in particular SMEs - also tightened considerably and more so in vulnerable euro area economies. Financial conditions have improved since, reflecting strong policy action and better market sentiment regarding euro area sovereigns and banks, but SMEs in these countries continue to experience difficulties in obtaining credit. For those that obtain financing, the interest rates are substantially higher than for SMEs in core countries. Furthermore, nominal interest rates have remained high as inflation has fallen, raising debt service burdens (Figure 1).

\section{European firms tend to be highly leveraged and reliant on bank financing, and SMEs} more so than larger firms. Bank loans represent 80 percent of euro area companies' debt, whereas U.S. companies use bond financing (accounting for 75 percent of their debt) (Figure 1). Also, compared with the United States, euro area companies have little equity, implying a higher leverage ratio-the average debt-to-equity ratio in the euro area is close to 70 percent, above the U.S. average of 60 percent. A large proportion of small firms have no debt, but when they borrow, their leverage tends to be higher and the reliance on bank finance larger (ECB 2014a). Only the largest firms are able to directly access capital markets through debt issuance (Giovannini and others 2015).

\section{More diversified funding sources could boost SME funding in normal times and} provide resilience against shocks. Broader access to finance would limit the exposure of SMEs to banking-sector difficulties and help ensure the flow of credit to viable firms, thereby reducing the vulnerability of the economy to financial shocks. SME securitization could also enhance financialsector stability by enabling risk-transfer from banks to a wider pool of investors beyond the banking sector. While there is considerable merit in developing markets for non-intermediated debt issued by SMEs, private equity, and venture capital over the medium term-a more vibrant SME securitization market could mobilize additional funding now (EVCA 2013). Starting with bankintermediated SMEs securitization would develop the market, which could later facilitate direct asset securitization - that is, more direct access of SMEs to capital markets (Jobst 2006 and 2008).

\footnotetext{
${ }^{2}$ See also Darvas (2013) and European Commission (2013a). For a perspective on Japan, see Lam and Shin (2012).
} 
Figure 1. Funding Conditions for SMEs in Europe
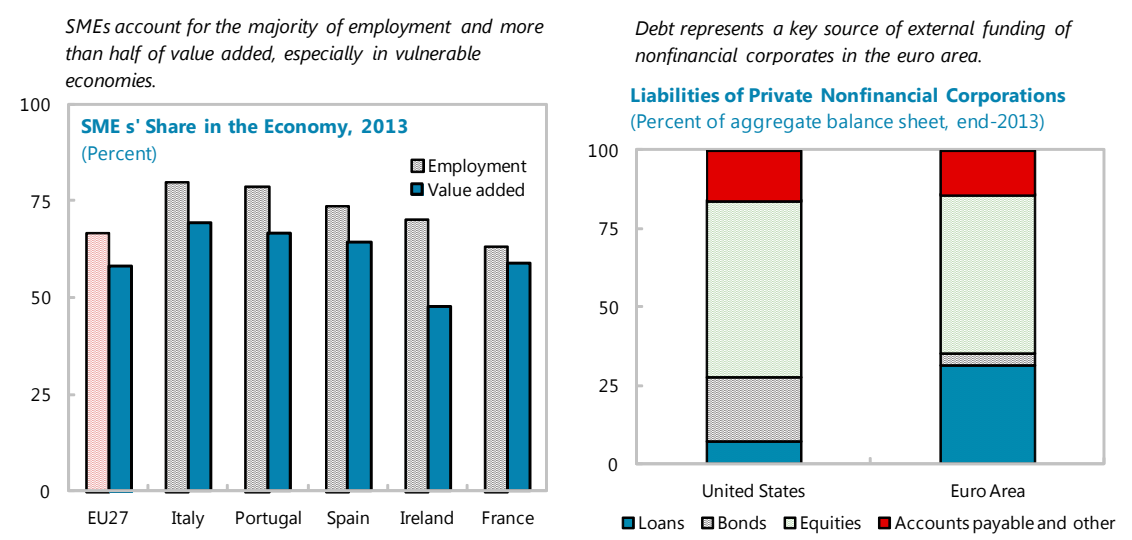

High leverage has weighed on investment and associated credit demand ...

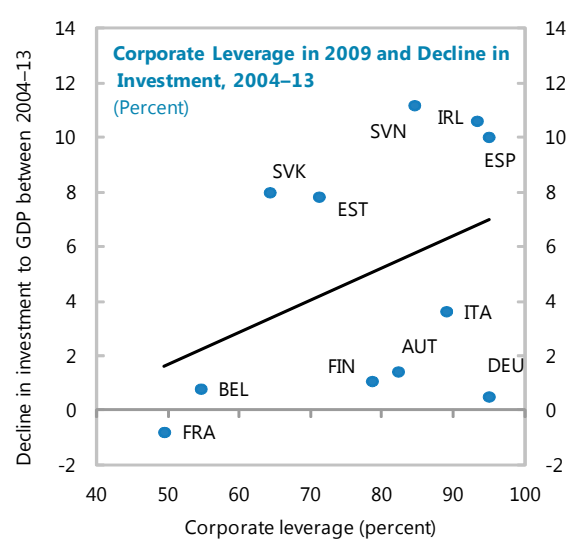
... but the increasing debt overhang reduces the
borrowing capacity.

Credit demand from the nonfinancial sector has been rising slowly ...
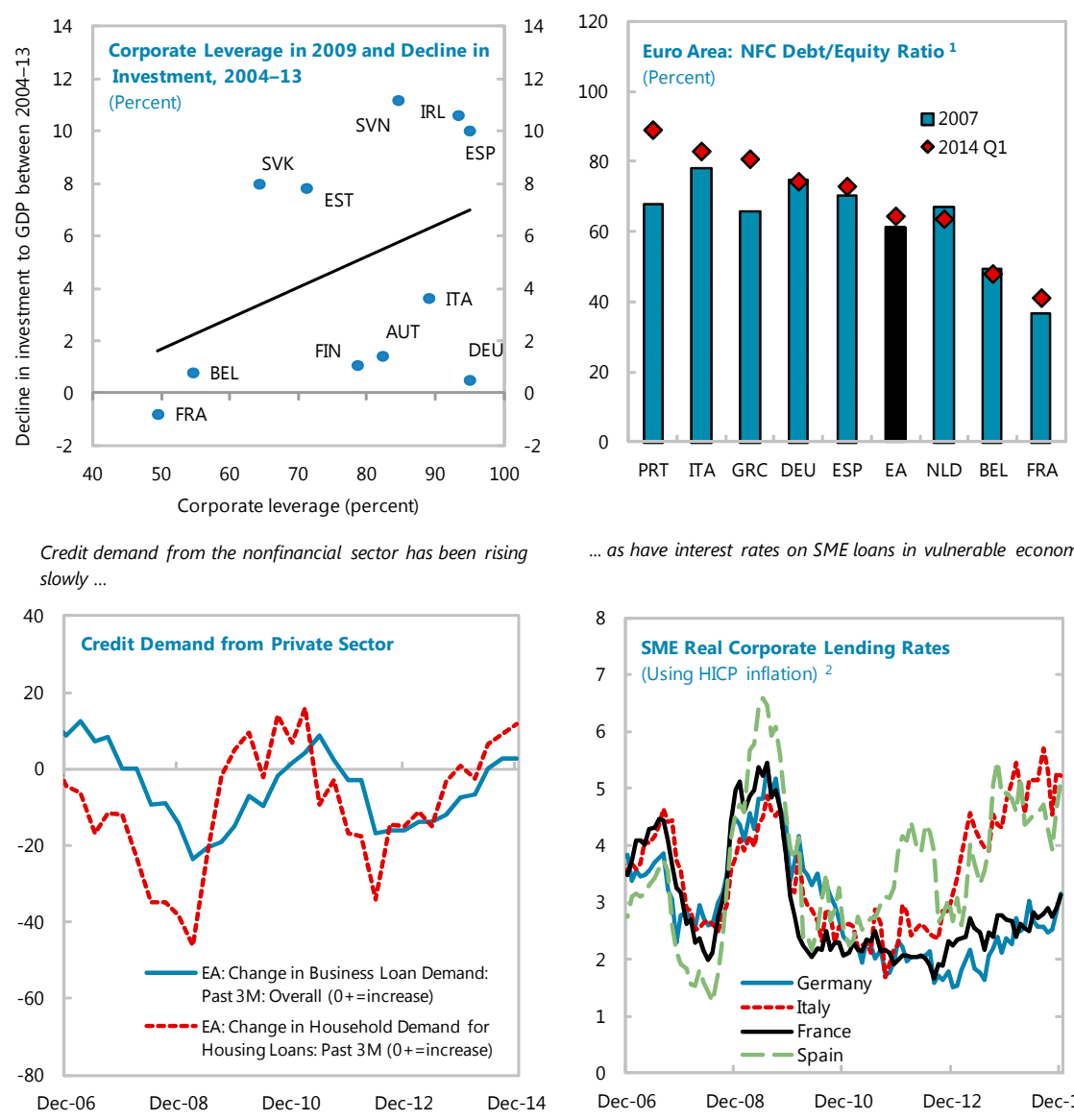

... as have interest rates on SME loans in vulnerable economies.

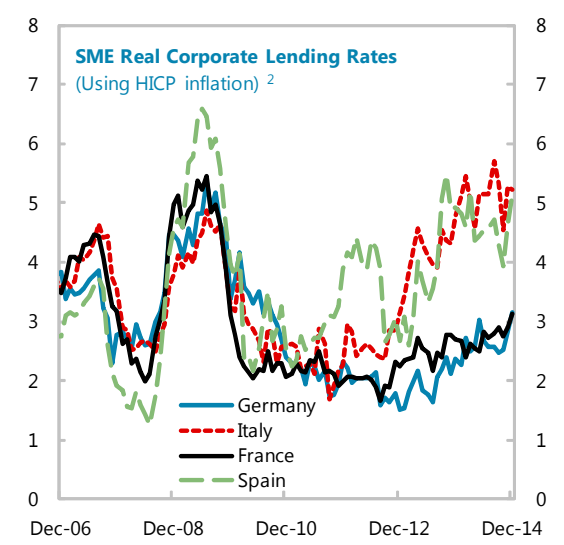

Sources: European Central Bank; Eurostat; Haver Analytics; and IMF staff calculations.

Notes: EA = euro area; HICP = Harmonised Index of Consumer Prices; NFC = nonfinancial corporations. Data labels in the figure use ISO country codes.

$1 /$ Debt at EA level is non-consolidated.

2/ MFI lending to corporations under $€ 1$ million, 1-5 years; real rates are calculated ex post using realized HICP inflation by country. 


\section{Box 1. Overview of the European Securitization Market}

The European term securitization market is relatively small and concentrated. The outstanding stock of transactions is about $€ 1.5$ trillion-more than half the size of the private-label U.S. market ( $€ 2.6$ trillion), excluding residential mortgage-backed securities (RMBS) issued by Fannie Mae and Freddie Mac (Galizia and Gentili 2014; IMF 2009 and 2011) (Figure 2, upper left panel). ${ }^{3}$ The European market is dominated by bank-sponsored RMBS, which amounted to about $€ 875$ billion (or about 60 percent of all collateral types) at end-2014. SME loan-backed securities (SME securitization) constitute only less than one-tenth of the total market (€121 billion). Moreover, market concentration is high, with a handful of countries accounting for the majority of the market (Jobst and Kiff 2011). Together, transactions from the Netherlands, Italy, Spain, Germany, and Belgium (in order of relative importance) accounted for about 81 percent of the securitization market in the euro area in 2014 (Figure 2, upper right panel). More than three-quarters of the outstanding SME securitization transactions in the euro area have been issued by entities in Spain, Italy, and Belgium. The scope for mobilizing additional funding now through securitization is considerable, given the large existing stock of SME loans. In 2004, just above five percent of euro area banks' outstanding SME loans were securitized.

The stock of outstanding securitization has contracted by about one-third since the start of the crisis. After peaking in 2008 (Figure 2, bottom right panel), new placements dropped to about one-fourth of their earlier size (and more than 40 percent below the post-1999 average), and amounted to less than $€ 80$ billion in 2014. The bulk of the decline in these markets reflects the approximately $€ 531$ billion (or about one-third) fall in the RMBS segment since 2009. But, in relative terms, the collateralized debt obligation and commercial mortgage-backed securities markets experienced larger declines, shrinking by almost half, while the SME market fell by about onethird, with net new issuance turning negative from mid-2012 (Figure 2, middle left panel). The decline of primary market activity continues to be much more profound than the contraction of credit supply to nonfinancial private sector borrowers in the wake of the financial crisis.

As securitization issuance has fallen, the retained portion has typically shrunk, but the reverse is true for SME securitization. At its peak, the general market was evenly split between retained and placed securitization. Since 2009, placed securitization has fallen by about a half. This mostly reflects the amortization of contracts prior to 2009 that have not been fully offset by new placements (Figure 2, bottom left panel). For the SME securitization segment, retention increased over time. Of new issuances, about two-thirds remain on banks' books, while for SME securitization transaction, almost 95 percent were retained in 2014 (Figure 2, bottom right panel). These retained securities can often be used as collateral for short-term funding from the Eurosystem (Figure 2, middle right panel). However, although the size (and scope) of the eligible asset pool for Eurosystem collateral has increased, the pool of eligible securitization transactions has actually dropped, likely reflecting the attrition of these assets and the high redemption rates over the recent past, rather than a tightening of collateral standards (which have been relaxed for some asset classes over the recent past, especially for structured finance transactions and outright credit claims).

\footnotetext{
${ }^{3}$ The U.S. figures also include credit card and student loan ABS (which are virtually absent in Europe) as well as collateralized debt obligations (CDOs), which account for a relatively small part of the European market (in contrast to the United States).
} 
Figure 2. Securitization in Europe
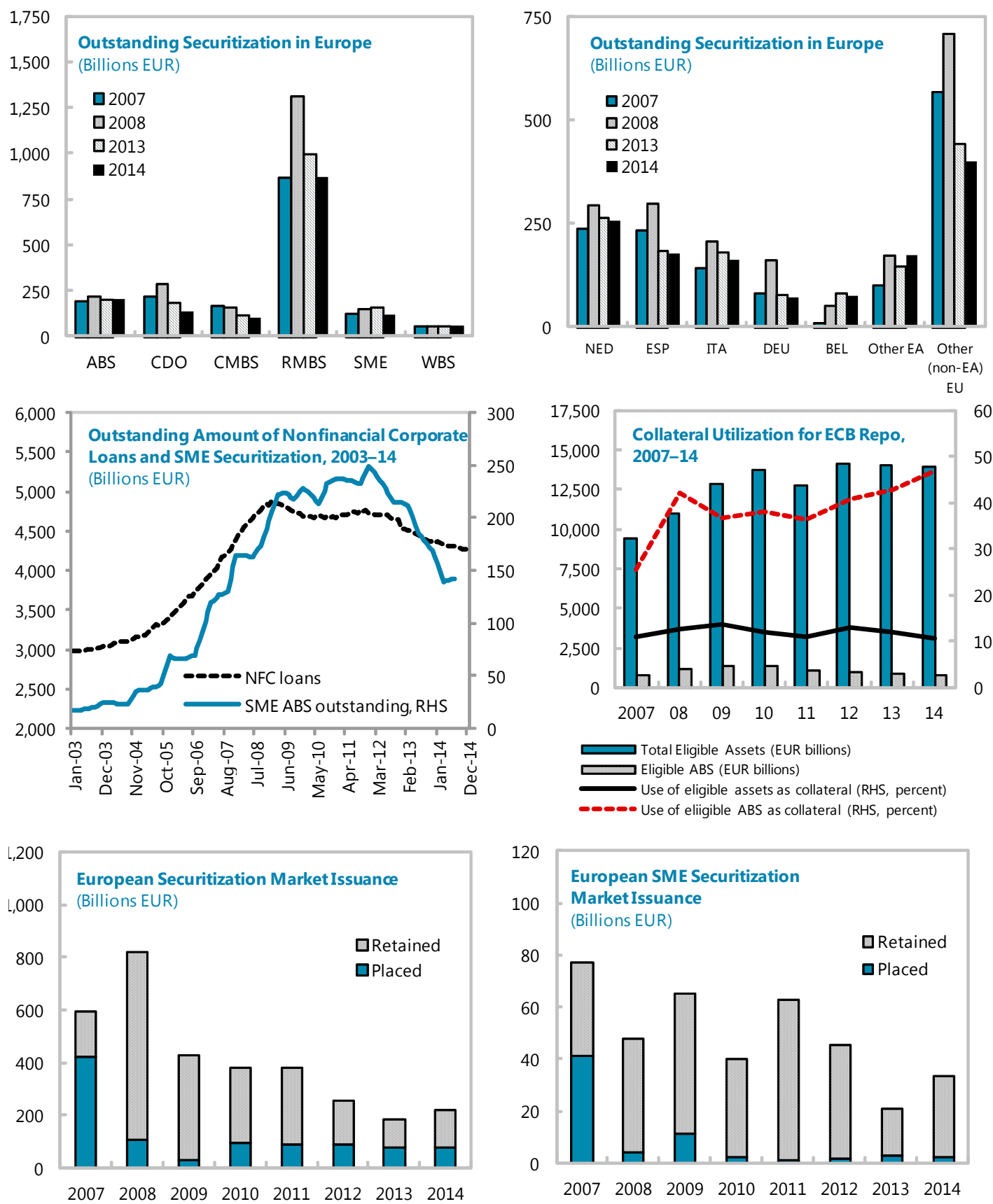

Sources: Association for Financial Markets in Europe (AFME), RBS estimates, ECB, and IMF staff calculations.

Note: $\mathrm{EA}=$ euro area; $\mathrm{HICP}=$ Harmonised Index of Consumer Prices; $\mathrm{NFC}=$ nonfinancial corporations. Data labels in the figure use ISO country codes. $A B S=$ asset-backed securities; $C D O=$ collateralized debt obligations; $C M B S=$ commercial mortgage-backed securities; $R M B S=$ residential mortgage-backed securties; $S M E=A B S$ backed by small and medium-sized enterprise (SME) loans; WBS/PFI = whole business securities/project finance initiatives. Europe is a geographic designation, including EU Member States and non-EU countries (top left panel). Other EA is the sum of other euro area members' outstanding securitization for which separate data are available. It includes Austria, Finland, France, Greece, Ireland, and Portugal (top right panel). Europe includes EU and non-EU countries (bottom panels). Data on asset-backed commercial paper (ABCP) and privately placed CDOs are not included. 1/IMF staff estimates based on data from Fitch Ratings, JPMorgan Chase \& Co., Bank of America Merrill Lynch, CRE Finance Council, and AFME (which also includes privately placed CDOs). 
5. SME securitization could enhance monetary transmission. The bank lending channel for the transmission of changes in policy rates is currently impaired by financial fragmentation across countries and banks' deleveraging efforts. With a more-developed securitization market, banks would be able to draw on more (market-based) funding sources for credit growth, thereby enhancing the traditional bank lending channel by strengthening the link between market interest rates for securitization instruments and the policy rate. ${ }^{4}$ SME securitization could also deepen the supply of high-quality collateral for securities financing transactions (SFTs), which would improve the price discovery process in asset markets.

\section{Simple, transparent, and comparable securitization instruments, in line with existing practice in Europe, allow risks and payoffs to be properly assessed. During the financial crisis} certain types of securitization have been indicted by some for compromising the incentives for originators to ensure minimum standards of prudent lending, risk management, and investment, with adverse consequences for financial stability. However, most securitization instruments in Europe showed remarkable resilience during the recent crisis (Box 1$).{ }^{5}$ Since the start of the financial crisis, defaults ranged across different studies between 0.6 and 1.5 percent on average for European securitization transactions and only 0.1 percent for European SME ABS (ECB 2014c). Moreover, European defaults were heavily concentrated in non-investment, grade-rated tranches, unlike in the United States where impairments affected even tranches with the highest credit ratings. This was partly because the underlying assets differ in their riskiness, but also reflected features related to bank-based issuance in Europe-such as traditionally conservative loan origination standards with high-equity participation and continuous servicing by the originator; adequate post-issuance performance monitoring and issuer due diligence; and the treatment of securitization as part of ongoing balance sheet operations with the funding purpose linked to real economic activity.

\section{Current EU initiatives facilitate bank-sponsored SME securitization, but have not been sufficient to jumpstart the market. The European Investment Bank (EIB) Group has a standing facility to guarantee SME securitization, which has been supplemented by additional EU-funded initiatives to revitalize the market (Box 2). The initiatives help attract new investors to SME}

\footnotetext{
${ }^{4}$ The off-balance-sheet treatment and asset-backed nature of securitization facilitates the assessment of credit risk at the time of issuance, which makes the credit channel of monetary policy more effective (Jobst, Goswami, and Long 2009) and enhances the economic effect of wholesale funding on monetary transmission. Disyatat (2011) shows that monetary transmission through banks that are reliant on wholesale funding occurs through the bank balance sheet channel where risk perceptions of banks' creditors play a critical role (in lieu of the traditional bank lending channel that operates through deposits). The regulatory capital relief from securitizing existing loans influences the pricing of new lending but does not translate into a broad increase of total capital unless a large share of the bank balance sheet is securitized. Thus, the potential negative effect of higher levels of capital on the effective transmission of interest rate changes to the supply of loans according to the standard bank credit channel (Bernanke [2007]; van den Heuvel [2007]; but also see Aiyar and others [2014] for a different view) is likely to be far outweighed by the positive effect of the bank-balance-sheet channel.

${ }^{5}$ Some SME loan-backed transactions with non-granular underlying reference portfolios, especially those including unsecured (mezzanine) loans, did experience significant downgrades and defaults during the financial crisis. But these transactions represented only a small part of the market and did not exhibit the high-quality properties that are considered in the next sections of this paper.
} 
securitization and support new lending to SMEs by requiring banks to provide new loans in proportion to guarantees received (Kraemer-Eis and Passaris 2015). All of the schemes are operated by the European Investment Fund (EIF), drawing on its considerable experience. The EIB's standing facility is used on a regular basis for the credit enhancement of senior and mezzanine tranches (€0.5-0.8 billion annually in past years) but remains small (much like the COSME Loan Guarantee Facility, which has a total amount of $€ 1.3$ billion available to invest in SME equity and guarantee SME loans and securitization). The modest uptake of the EU SME Initiative, with only Spain expected to participate in the securitization option, can be partly attributed to eligible EU structural funds already having been committed to other projects. SME financing under the EFSI could provide significant scale to supporting SME securitization but has just started. Overall, the current initiatives appear insufficient to jumpstart the market in terms of:

- Capacity. Available resources are limited compared to banks' SME loan portfolios, given the small committed amounts and some overlap of financing across EU initiatives, such as COSME, Horizon 2020, and the EIB/EIF (Table 1).

- Scope. Support is focused narrowly on bank lending, falling short of mechanisms to solicit nonbanking funding sources and schemes that would allow direct capital market access.

- External impediments. The lack of sufficient coordinated effort to deal with other factors that are holding back SME securitization, such as insufficient regulatory differentiation and incomplete market infrastructures, reduces the effectiveness of support.

\section{A push to develop SME securitization would go hand in hand with efforts to integrate}

EU capital markets. SME securitization could be an important element of more developed and integrated capital markets - the major objective of the Capital Markets Union. Many of the general obstacles to cross-border long-term investment also impede SME securitization, such as the limited access to credit information and differences across securities laws, as well as national debt enforcement and insolvency regimes. EU actions to promote SME securitization could therefore help set the stage for a Capital Markets Union, and vice-versa. 


\section{Box 2. EU Initiatives to Support SME Securitization}

The European Investment Bank (EIB) Group's standing facility to guarantee SME securitization is supplemented by several EU initiatives:

European Investment Fund (EIF) Credit Enhancement. The facility provides credit enhancement to senior and mezzanine tranches of SME securitizations. Financial institutions can apply a zero risk weight on tranches guaranteed by the EIF, given its Triple-A credit rating. This "rating uplift" mitigates the influence of "sovereign ceilings," which cap the rating of banks at the level of the sovereign, and facilitates market access to smaller banks with low issuer ratings.

EU SME Initiative (European Commission 2014f). The initiative aims to restart the SME securitization market by boosting underwriting capacity and providing credit enhancements to third-party investors. Countries commit EU structural funds and receive additional funding from EU funds and the EIB Group for SME loan guarantees or for SME securitization. Despite the favorable terms, only Spain participates so far, with the terms of the SME securitization option still to be finalized (negotiations are advanced with Malta on participation in the loan guarantee option).

COSME Loan Guarantee Facility (Securitization Option) (EIB 2014). The financial instruments of the Loan Guarantee Facility under the EU's COSME (Competitiveness of Small and Medium-sized Enterprises) Program will dispose a total of $€ 1.3$ billion over 2014-20, for investments in SME equities and the provision of guarantees on SME loans and securitization instruments. While its predecessor (the securitization window under the Competitiveness and Innovation Framework Program), was only used once during 2007-13, the expectation is that financial institutions will find the new design more attractive.

European Fund for Strategic Investments (EFSI) (European Commission 2015c and 2014g). A €21 billion EU fund will be created backed by $€ 8$ billion EU resources and $€ 5$ billion contribution from the EIB's capital. The EFSI will be set up at the EIB, with the aim of boosting investment by $€ 315$ billion over 2015-17, of which $€ 75$ billion should be allocated to SMEs and mid-cap companies. To this end, the fund will have the option to support highquality SME securitization instruments, potentially by taking a first-loss piece.

EU initiatives have been supplemented by national efforts, most notably the French Euro Secured Note Issuers scheme. Through the setup of a Special Purpose Vehicle (SPV), the French scheme helps banks securitize credit claims on nonfinancial corporations to create securities that can be easily used for transaction purposes and for collateral purposes. The scheme enables double recourse to the issuing bank and to the pledged collateral, and is hence similar to a covered bond in economic terms, although the legal structure is different and the collateral consists of claims on nonfinancial corporations that are not eligible for legislative covered bond schemes. The SPV set-up costs are mutualized, but there is no risk-sharing among the banks. Five French banks are participating and have issued notes worth €3.65 billion. The scheme is open to all European banks, and interest in the scheme in other euro area countries could be enhanced if the notes become eligible for Eurosystem liquidity support. 
Table 1. EU Support Initiatives for SME Securitization

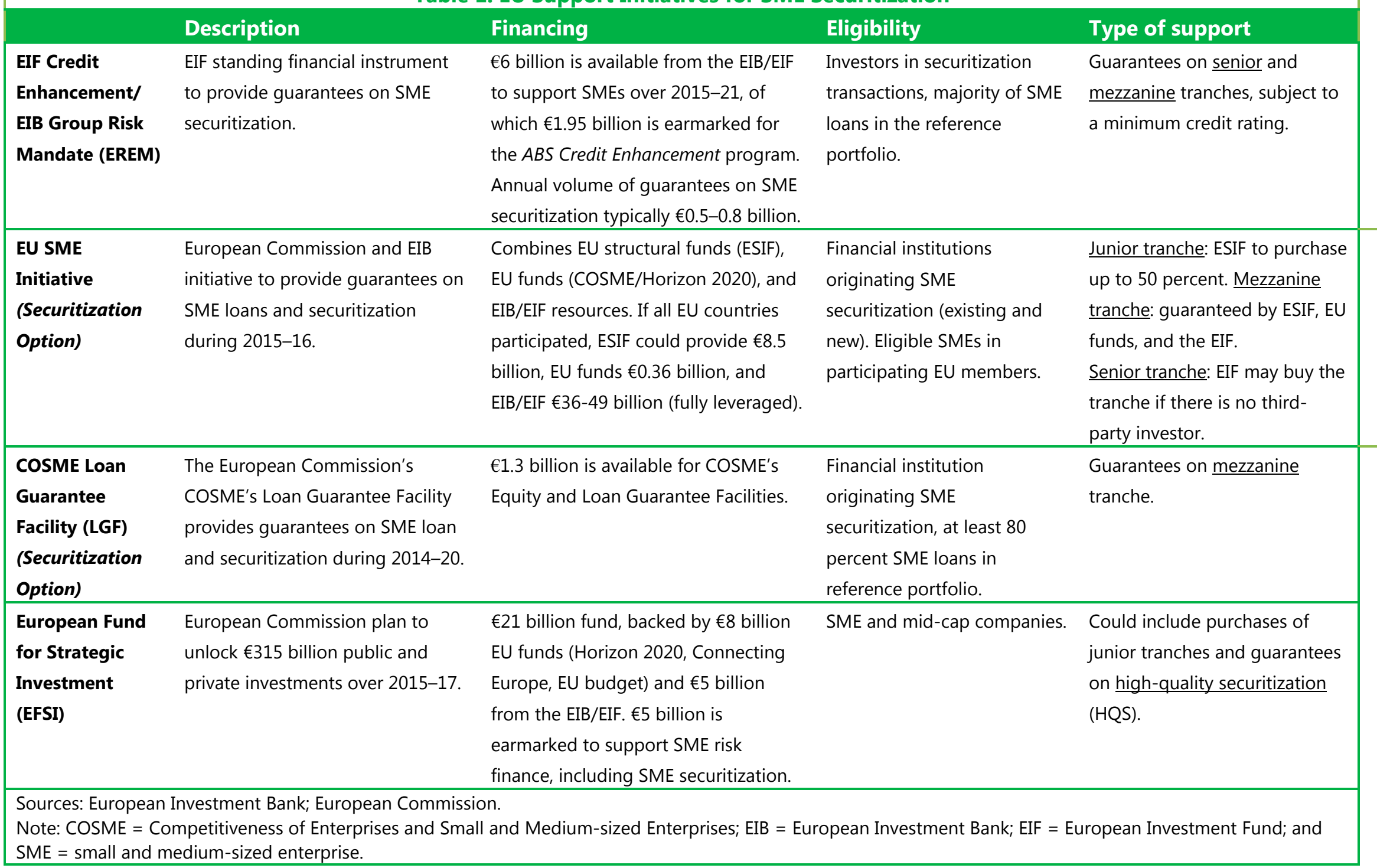




\section{IMPEDIMENTS TO SME SECURITIZATION}

9. Various regulatory and structural hurdles inhibit the emergence of a well-functioning and liquid SME securitization market. ${ }^{6}$ Regulatory hurdles relate to capital and liquidity requirements for banks and insurers that do not sufficiently differentiate credit quality and the type of underlying asset structures, and therefore weaken the investor base. Structural market factors include high issuance cost and factors that hinder cross-border investment more generally, such as differences in debt enforcement and fragmented national insolvency regimes and the lack of harmonized credit information across EU countries. Resolving these hurdles will help SME securitization to be priced in a way that meets the needs of issuers and investors. ${ }^{7}$

\section{A. Insufficient Regulatory Differentiation}

10. Despite ongoing reforms there remains insufficient regulatory differentiation of securitization instruments. As demonstrated by the financial crisis, misaligned incentives between investors and originators, ${ }^{8}$ inadequate risk management practices of issuers, and deficiencies in regulatory structure, valuation methods, and prudential oversight can open the floodgates to opaque, often highly leveraged and complex asset structures that minimize risk to originators at the expense of magnifying systemic vulnerabilities (Shin, 2009; Franke and Krahnen 2008). Simple, transparent, and comparable structures, encouraged by enhanced eligibility requirements for the use of securitization transactions as collateral within the Eurosystem, have enhanced liquidity and reduced valuation challenges. However, past and current efforts aimed at resolving incentive problems in securitization remain insufficient to revitalize the market without amending prudential standards to enable these structures to be clearly identified and hence priced differently from more complex securities.

\section{Recent EU regulatory initiatives aimed at favoring high-quality securitization (HQS)} represent a step in the right direction. ${ }^{9}$ The concept of HQS has already been used in the Solvency II regime for EU (re)insurance companies (EIOPA 2013; European Commission 2014d), and

\footnotetext{
${ }^{6}$ The Bank of England and ECB (2014a and 2014b) published a comprehensive review of existing obstacles to a better functioning of the securitization market in the European Union, which includes some arguments that are also reflected in these recommendations.

${ }^{7}$ An earlier paper contains a detailed discussion of the underdeveloped nature of the European SME securitization market, and the constraints it faces (Al-Eyd and others 2014).

${ }^{8}$ See Segoviano and others (2013) as well as Jobst (2009) for a comprehensive analysis of incentive problems in securitization.

${ }^{9}$ Currently, the legal framework for securitization in the EU is determined by a large number of legal acts, including the Capital Requirements Regulation (CRR) for banks, the Solvency II Directive for (re)insurers, and the Undertakings for Collective Investment in Transferable Securities (UCITS) Directive and Alternative Investment Funds Managers Directive (AIFMD) for asset managers. Legal provisions, most notably the Credit Rating Agency Regulation (CRA3) and the Prospectus Directive, govern the information disclosure and transparency aspects of securitization. Also nonlegislative provisions also play an important role, especially accounting standards (for example, IAS39, IFRS 10, and IFRS 7).
} 
in the implementation of the liquidity coverage ratio (LCR) and the leverage ratio for EU banks (European Commission 2014b and 2014c). As part of the recently published Green Paper on the Capital Markets Union (CMU) earlier this year, the European Commission (2015a and 2015b) has started its own consultation process on the development of a (legislative) proposal for encouraging HQS. This will influence the final implementation of regulatory standards for securitization transactions in the EU. ${ }^{10}$ Other reforms have addressed various incentive problems and disclosure requirements. The European Commission has introduced uniform risk retention ("skin-in-the-game") requirements, which have been in place since 2011 (Articles 394-399 of CRR). Moreover, the European securities market regulator established enhanced disclosure requirements and transparency standards for structured finance instruments (ESMA 2014), and central banks have made loan-level information a pre-condition for assessing $A B S$ as eligible collateral for refinancing operations (Bank of England 2010 and 2014; ECB 2010, 2012, and 2013a).

\section{Current regulations tend to impose high capital charges on securitization instruments relative to other funding instruments of similar credit risk. While most of the current EU} regulatory initiatives are unambiguously positive for the development of securitization markets, they do not go far enough in redressing this regulatory imbalance. Further work is needed to introduce greater differentiation of asset structures within the securitization market and ensure equitable treatment across different forms of structured finance (that is, with the proposed regulatory requirements, senior tranches of securitization transactions compare unfavorably against other funding instruments, such as senior unsecured debt or covered bonds (Table A1 in Annex I)). ${ }^{11}$ Disproportionately high regulatory capital charges risk narrowing the investor base, which in Europe is mostly comprised of regulated financial institutions (banks, (re)insurance companies, pension funds, and mutual funds). In fact, in current market conditions, the proposed capital charges for even highly rated transactions would reduce balance sheet leverage to a point where insurance companies, and to a lesser extent banks, can no longer achieve a sufficient return on equity based on current profitability (Box 3). ${ }^{12}$ Therefore, the regulatory cost of securitization remains too high relative to the cost of holding the underlying SME loans as originating bank or investor in loan sales (or alternative fixed income instruments with comparable risk-return properties). ${ }^{13}$

- Banks. The final version of the revised Securitization Framework by the Basel Committee on Banking Supervision (BCBS 2014) defining the risk-weighted assets (RWAs) for securitization exposures (and the hierarchy of approaches for calculating RWAs) effectively raises the capital intensity of even simpler (or less risky) securitization transactions relative to other forms of

\footnotetext{
${ }^{10}$ To date, we can distinguish three key proposals for HQS: (1) Simple-Transparent-Comparable Securitization (STC) by EBA (2014); (2) Simple-Standard-Transparent Securitization (SST) by the BCBS/IOSCO Joint Task Force on Securitisation Markets (2014); and (3) Simple-Transparent-Standardized Securitization (STS) by the European Commission (2015b). See also Annex 1.

${ }^{11}$ Covered bonds are on-balance-sheet bank debt instruments with dual investor recourse, secured by a (narrowly defined) cover pool of mortgage loans (property as collateral) or public sector.

12 Other types of investors, typically hedge funds, represent only a small portion of the market.

${ }^{13}$ Note that the focus of reducing the regulatory cost of investing in securitization tranches should be focused on nonbank institutions to encourage the widest possible diversification of credit risk. However, the capital requirements for banks remain especially relevant for the mezzanine tranches, which might be partially retained by the issuer.
} 
structured finance held by banks, rendering differentiation of these instruments based on actual market performance largely irrelevant. ${ }^{14}$

- Insurers. The capital charges under the Solvency II Directive for insurers investing in securitization transactions are higher than those for other assets with comparable risks. ${ }^{15}$

\section{EU regulations affecting the liquidity risk management and investment demand of regulated institutions disadvantage even HQS relative to similar asset types:}

- Liquidity risk standards. The liquidity coverage ratio (LCR) aims to ensure that banks hold enough high-quality liquid assets (HQLA) in their liquidity buffer to cover expected net cash outflows over a 30-day stressed period. The EU's implementing legislation for the LCR includes an expanded range of HQS instruments in HQLA (SME, auto and consumer loan ABS in addition to RMBS), but only up to a cap of 15 percent and with haircuts of 25 to 35 percent (European Commission 2014c). This represents a more favorable treatment than the Basel definition of HQLA, which mostly excludes securitization instruments altogether (with the exception of highly rated RMBS). Yet, this still falls short of leveling the playing field between covered bonds and securitized transactions, since highly rated covered bonds can constitute up to 70 percent of HQLA, at a 7 percent haircut (European Commission 2014b). Thus even well-designed securitization transactions remain unattractive relative to covered bonds.

- Indirect investment restrictions for institutional investors at the national level. While the EU Life Insurance Directive (European Commission 2002) defines a clear list of eligible assetswhich includes SME-backed securities - and maximum limits for investment in any asset class, EU countries may adopt a more stringent criteria for investment in particular asset classes. For pension funds, the Institutions for Occupational Retirement Provision (IORP) Directive (European Commission 2014e) remains deficient in reining-in national restrictions on cross-border diversification of investments. Restrictions range from the obligation to buy only domestic government bonds to limits on investments in any nongovernment debt (often combined with a high minimum credit-rating requirement). Although the actual portfolio allocation of many pension funds falls short of these statutory limits (and thus do not present a binding constraint), these observed limits have encouraged weakly diversified asset allocation strategies and skewed demand away from alternative investments, especially if high fixed costs (reporting, research) for a limited supply of difficult-to-value assets demands a critical scale of investment. ${ }^{16}$

\footnotetext{
${ }^{14}$ The framework introduces a more risk-sensitive approach to the assessment of risk weights for investment graderated tranches, which increases with the maturity term of the security (BCBS 2014).

${ }^{15}$ Note that Solvency II assigns a lower capital charge for covered bonds compared to other non-government and/or unsecured assets if they comply with (1) Article 129(4) and (5) of CRR and Article 52(4) UCITS as high-quality liquid assets (HQLA) and (2) the transparency criteria defined in Article 129(7) of CRR.

${ }^{16}$ The institutional investor base is also detrimentally impacted by regulations restricting market fund investments and liquidity restrictions in Article 19 of the UCITS Directive.
} 


\section{Box 3. The Impact of Capital Regulation on Banks and Insurance Investment in SME Securitization and Covered Bonds}

A simple cost-benefit analysis can illustrate how recently proposed capital charges affect banks' and insurance companies' trade-off between investing in either securitized or non-securitized SME loans (or other similar types of securities, such as covered bonds). For these "regulated" investors, the interaction of their desired return on equity (RoE) and the degree of leverage implied in the economic cost of capital for any given asset return determines whether the proposed capital charges under the relevant regulatory regime (Basel III-Securitization Framework [BCBS 2014]) and Solvency II-Capital Charges for Long-term Investment (European Commission 2014) are binding or not.

Figure 3. European Securitization: Market-Implied Regulatory Capital Charge for Banks and Insurers at Current Market Prices, as of end-December 2014

(Percent)

\section{Banking Sector \\ (Basel III/CRR)}

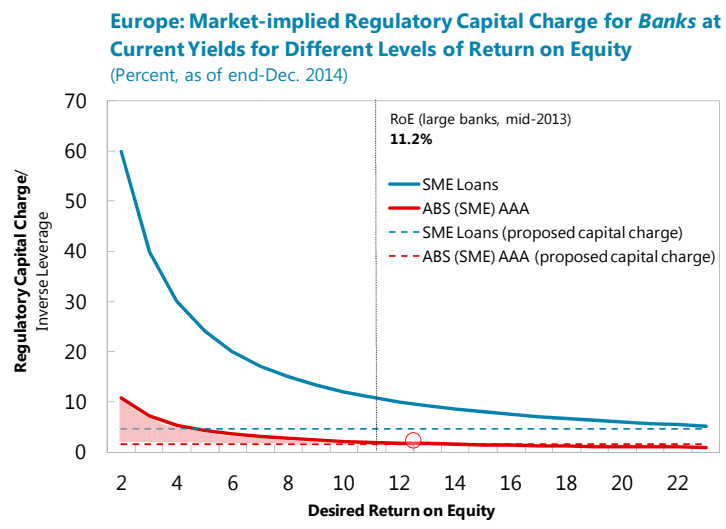

Insurance Sector

(Solvency II)

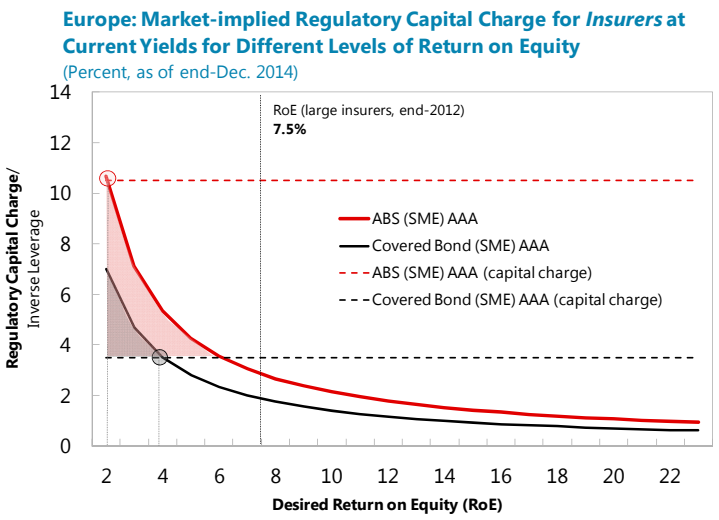

Sources: Basel Committee on Banking Supervision; Bloomberg, L.P.; European Commission; and IMF staff calculations.

Note: The calculations are based on the average yield of European benchmark AAA-rated asset-backed securities (ABS), the average net interest margin of SME lending in the euro area after provisioning (20\%), and the average EU benchmark government bond yield as of end-December 2014 (0.64\%) as the risk-free interest rate; the return on equity (RoE) is taken after taxes (35\%). This analysis reflects the standardized/external ratings-based approaches under the proposed regulatory regimes for banks and insurers; for the capital charge of insurers, a maturity tenor of five years and compliance with "Type 1 securitization" criteria-that is, high-quality securitization (HQS) was assumed for the ABS to derive the solvency capital requirement (BCBS/IOSCO 2014; EIOPA 2013; European Commission 2014b, 2014c, and 2014d); for an assessment of internal model-based approaches in banking, for instance, one would need to apply the internal ratings-based approach (IRBA) to rated tranches (and the supervisory formula approach (SFA) to unrated tranches retained by originators). For investing banks, unrated tranches would need to be fully deducted from capital unless the application of the SFA is granted by the national supervisor.

At current market prices, banks have an incentive to hold SME loans rather than invest in highly rated securitization transactions backed by the same credit risk. The blue ("SME loans") and red ("ABS (SME) AAA") curves (shown in the left panel, Figure 3 depict feasible combinations of the regulatory capital charge ( $y$-axis) and the corresponding RoE ( $x$-axis) at the current yield/net interest margin of the respective asset. A higher capital charge implies lower leverage, decreasing the potential RoE for a given asset return and vice-versa (all else equal). The intersection of these curves with the dotted horizontal lines showing the proposed capital charges for the respective asset illustrates that investment in highest-rated senior tranches of ABS would result in an RoE of less than 12 percent (as of end-December 2014). This is only slightly above the current benchmark RoE for banks and far below the RoE that banks would earn by simply holding the SME loan on their books (with the intersection, or asymptotic convergence, of the blue curve and line occurring to the right of the current RoE). Thus banks have little incentive to securitize their holdings of SME loans.

For insurance companies, regulatory incentives favor holding covered bonds rather than securitization transactions on the same credit risk. This can be seen from the fact that the intersection of the black curve and line lies to the right of the intersection of the red curve and line (right panel chart). Note, however, that the regulatory regime is not particularly conducive to holding either instrument; even the "break-even" RoE from holding covered bonds lies significantly below the current benchmark RoE for large insurers.

These observations highlight that current regulatory incentives are stacked against securitization. In particular, the regulatory treatment of non-banks in the area of capital adequacy impedes the broadening of the potential investor base. The impact of current monetary easing on risk premiums (and the current yield/net interest margin) influences these results but is unlikely to affect the overall outcome. 


\section{B. Incomplete Market Infrastructure and Obstacles to Cross-Border} Investments

14. SME securitization can be costly. The elevated upfront costs of structuring SME-backed transactions, the difficulty in generating enough returns to attract investors, and the lack of a sufficiently large investor base render SME securitization expensive. Upfront costs include sunk costs, such as setting up IT systems to handle the granular information and variety of collateral related to SME loan portfolios, and costs related to pooling, legal documentation, due diligence, credit ratings, and credit enhancements (for example, high subordination levels for senior tranches, overcollateralization, and interest reserve accounts).

- Pooling. Certain conditions must be satisfied to ensure a loan's suitability for pooling, raising the cost of due diligence. Among these conditions, a few are crucial: a clean credit history, sufficient maturity tenor with a predictable cash flow stream, clarity on collateral and its availability, and sufficient sectoral diversification. From a bank's perspective, achieving a critical mass of loans with such characteristics is more difficult in the SME sector than, for example, in the residential mortgage sector where there is more uniformity of loans and credit scoring, longer maturity tenors, and regularity of payment streams due to amortization. Moreover, the complexity of information and different reporting requirements complicates the assessment of credit risk across jurisdictions and creates a home bias.

- Commoditization. Once a pool of loans is identified, legal documentation must be drawn, and ratings must be solicited from an external credit assessment institution (ECAI). Regarding the latter, higher uncertainty about the credit risk assessment of SME loans typically requires a compromise on the part of issuers, for example by providing greater investor protection at more senior tranches (through higher credit enhancement than comparable securitization on different asset classes). Overall, these costs provide a degree of transparency, but they must be balanced against the size of the pool to ensure an adequate cost ratio. Typically, the larger the pool, the less costly are such considerations.

- Interest margin of securitized assets. Investors require a favorable risk/return profile. This can be achieved through a sufficiently high-yielding asset (relative to risk), an inherently less risky asset (relative to yield), or a combination of these. However, it can be difficult for a bank to create a high-yielding asset with adequate differentiation between tranches from a heterogeneous pool of SME loans that are costly to securitize and generate relatively low returns (due to a high degree of collateralization). This contrasts, for example, with the securitization of high-yielding credit card payments. 
Figure 4. Euro Area: Private-Sector Credit and Average Recovery Rate on Loans Relative on Changes in Nonperforming Exposure after the ECB's Asset Quality Review
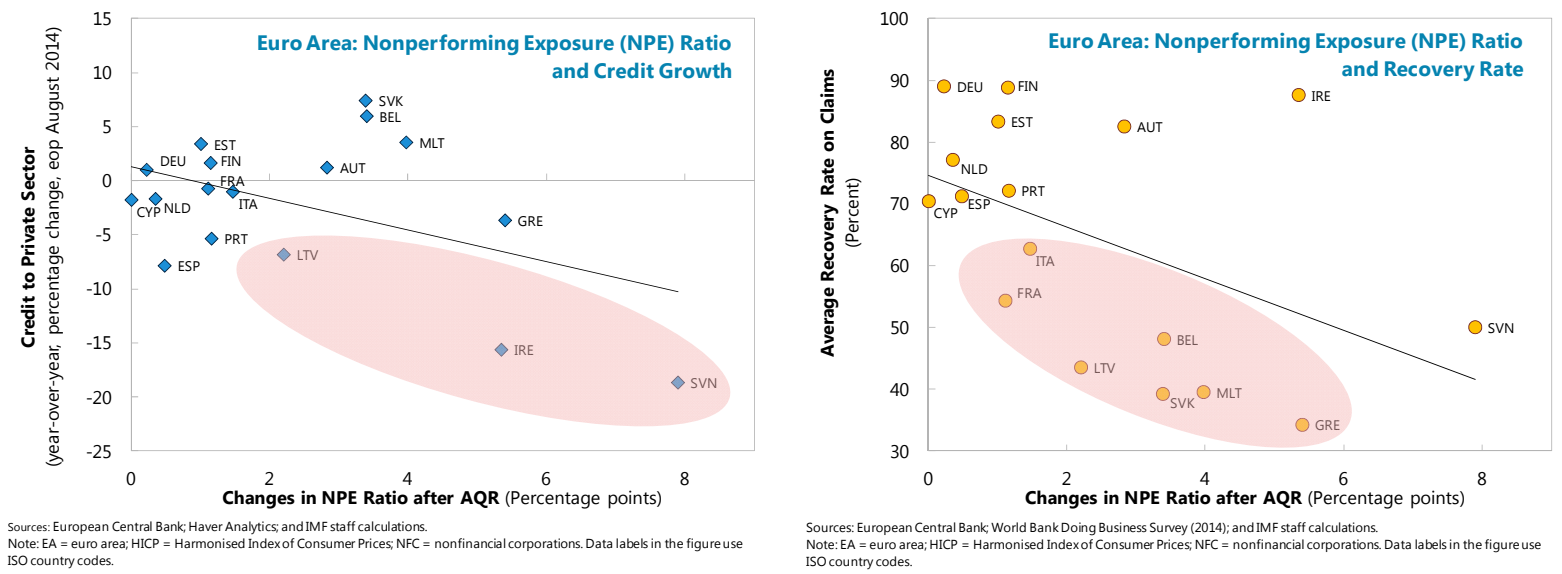

15. Weak enforcement of claims and collateral access in distress situations limit investor interest in SME securitization. Effective debt enforcement and insolvency are essential components of the workout toolkit, as they provide mechanisms for banks to enforce claims on collateral in a predictable, equitable, and transparent manner, while protecting and maximizing value for all interested parties. The ability to enforce secured credit claims (in particular under foreclosure) has a direct influence on the credit assessment of securitization transactions but depends on several legal factors. First, SMEs' ability to grant security interest over their inventory, equipment, or receivables varies widely across EU countries, with different legal techniques and outcomes. A well-functioning security interest framework is important to ensure that securitized claims have a first-priority access to collateral. Second, debt enforcement regimes vary considerably across EU countries, from out-of-court enforcement to lengthy judicial processes, with large differences in the speed and rate of recovery. Third, weak regimes for collective enforcement of credit claims in many EU countries can hinder securitization, though the plurality of creditors in insolvency proceedings typically implies that the ability to recover claims, even if secured, is much smaller. Different enforcement and insolvency frameworks across EU countries also make it difficult for banks to pool SME loans across national borders, creating a home bias for investors. All in all, these factors may hinder SME securitization by reducing the expected recovery rates on underlying SME loans, with negative implications for credit conditions in cases of high asset-impairment levels (Figure 4).

\section{Weak financial reporting requirements and lack of harmonized data reduce the scope}

for cross-border transactions. The heterogeneity of SME loan portfolios and the national character of credit registries in EU countries mean that SME loans typically take the form of relationship lending. While banks could maintain this relationship by acting as originators of SME securitization, enhanced access to comparable SME financial data would boost investor interest in SME securitization and could also facilitate the development of SME securitization that is not intermediated by banks. 
17. Banks' need for collateral to support secured funding during the crisis has skewed securitization activity toward a limited range of asset types and "inefficient" asset structures. In many cases, transactions have been structured exclusively as collateral for central bank refinancing. They comprise large retained and "over-priced" mezzanine and junior tranche(s) supporting a small "under-priced" senior tranche, which carries very low default risk but absorbs most of the asset spread generated from the underlying asset portfolio. This limits the supply of transactions involving significant credit risk transfer or asset types that are generally more costly to securitize, such as SME loans.

\section{POLICIES TO REVITALIZE SME SECURITIZATION}

\section{A. Ensuring Greater Regulatory Differentiation of High-Quality Securitization}

18. Simple, transparent, and comparable securitization structures can help broaden the investor base, but require clear and effective criteria guided by generally accepted principles. Greater differentiation of securitization products for prudential purposes is necessary. Prudent securitization can play a vital role in matching firms and projects with the funding from a diverse group of investors. But to fulfill this role, there must be clear criteria to distinguish simple, transparent, and prudently structured transactions from transactions with more complex, opaque structures, ensuring that investors are able to understand and analyze the risks of their investment, thus facilitating appropriate pricing and a more efficient allocation of risks.

19. This paper proposes a principles-based definition of high-quality securitization (HQS), with additional specific criteria applying to SME securitization. HQS criteria are aimed at aligning the incentives of relevant agents (loan originators, intermediaries, and credit rating agencies) for all activities of the securitization process, and can be mapped to the three fundamental objectives of HQS - simplicity, transparency, and comparability (Box 4 and Annex II (in separate document) contain a detailed description). The key requirements to qualify for HQS are based on the following attributes:

- Strict rules (and enforcement) should be observed regarding asset eligibility and quality, with conservative loan origination standards (including by imposing risk-retention rules ("skin in the game") and avoiding "originate-to-distribute" business models), ${ }^{17}$ a strong funding relation to real economic activity, and a requirement that the cash-flow generating reference portfolio is self-funded and comprises only one type of asset ("homogeneity"). The scope of HQS should also include non-senior tranches of robust structures (that is, securities with features that are

\footnotetext{
17 "Originate and distribute" relates to the rising risk of moral hazard if the originator is entirely removed from the performance of securitized assets. Annex 1 further clarifies this point.
} 
consistent with the general properties underpinning the HQS concept), especially via improvement of data and analytics. ${ }^{18}$

- Transactions should fulfill rigorous disclosure requirements at both asset and transaction levels, with standardized documentation and reporting of portfolio quality at inception and post-issuance performance monitoring.

- For SME securitization more specifically, the SME and the SME loan portfolios should meet certain criteria of eligibility, diversification, cash flow, and track record to limit the underlying risk.

20. HQS transactions should receive more lenient regulatory treatment than non-HQS transactions, reflecting lower risk and greater transparency. As discussed in previous sections, there is insufficient regulatory differentiation across different types of asset structures of securitization transactions and relative to other forms of structured finance, such as covered bonds and leveraged loans (Jobst 2015). The regulatory "cost" of holding securitized exposures is too high relative to the cost of holding the underlying loans (in the case of banks) or investing in alternative asset classes that carry similar credit risk, such as covered bonds (in the case of insurance companies and pension funds). This acts as a deterrent to securitization activity. ${ }^{19}$

- Further reducing the capital charge on HQS for non-bank investors could encourage greater issuance while still maintaining financial stability safeguards.

- Greater differentiation in setting haircuts for eligible HQS for liquidity risk management purposes would increase banks' appetite for a wider range of securitization structures of sufficient credit quality.

- Revising investment restrictions for institutional investors. Once the supervision and regulatory framework is strengthened, restrictions on institutional investors (insurance companies, pension funds, and mutual funds) could be reviewed and revised to prudently encourage alternative investments that benefit SME financing.

21. A well-designed HQS regime would enhance, rather than supplant, the relevance of granular risk assessment of securitization transactions for regulatory and prudential purposes. Indeed, comprehensive risk analysis and disclosure requirements at both the asset and transaction level should be a prerequisite for HQS certification. This would establish HQS as a complement rather than a substitute for current regulatory standards, promoting greater transparency and comparability. It would facilitate risk assessment by investors and help enhance the marketability of

\footnotetext{
${ }^{19}$ In this proposal, comprehensive external credit assessments and disclosure requirements at both the asset and transaction level ensure the marketability of securitization transactions; and this is a prerequisite for HQS certification.
} 
securitization transactions by overcoming well-recognized pitfalls of the securitization process (misaligned incentives, insufficient risk management, and lack of due diligence).

\section{Box 4. Summary of Proposed Attributes of High-Quality Securitization and Additional Criteria for SME Loans as Reference Assets}

This box summarizes the proposed principles-based definition of high-quality securitization (HQS) as the regulatory foundation of a safer securitization market, building on ongoing efforts by other institutions and market initiatives to define standards for simple, transparent, and comparable asset structures (BCBS/IOSCO 2014; EBA 2014; EIOPA 2013). To deepen SME access to capital markets, the proposal also introduces criteria for SME loans as securitized assets. See Annex II, which has been published as a separate document.

\section{General Criteria}

1. Asset characteristics-underwriting process and asset eligibility: (1) sound underwriting practices (that is, assets selected as part of ongoing balance sheet operations (with seasoned, senior, and fully disbursed loans only) and without impacting the risk management and control of the originator ("no originate-to-distribute") and prohibition of self-certification; (2) strong funding relation to real economic activity (that is, satisfies credit demand by nonfinancial corporations and households) and exclusion of re-securitization; (3) the eligibility of assets (determined by materiality of assets to originator's business, the homogeneity of cash flows (without ex ante exclusion of a particular asset type), the restricted use of derivatives/transferable financial instruments, the requirement of full funding and enforceability, the exclusion of encumbered and/or nonperforming assets, and the availability of a payment record of the borrower); and (4) quality of assets and transaction (determined by an external assessment and criteria that ensure the marketability of the asset structure and minimize tranche retention above the regulatory minimum to enable credit risk transfer).

2. Structural features: (1) asset transfer (legal separation and bankruptcy remoteness, no severe claw-back provisions, obligor rights in compliance with applicable consumer protection legislation, legal validity of the transaction, and no transfer of risk that are unrelated to the risk profile of securitized assets); (2) continuous servicing (via retained obligation by the issuer or pre-determined agent) and sufficient material net economic interest of originator/issuer in contractual performance ("skin in the game"); (3) replacement of derivative counterparties/liquidity providers upon default or insolvency; and (4) transparent and pre-determined payment process (self-liquidating asset portfolio without reliance on borrowings and asset sales, "pass through" payment structure of non-revolving and "early determination triggers" of revolving portfolios, and no circularity of support mechanisms due to contingent credit/liquidity arrangements with related parties).

3. Comprehensive documentation and reporting requirements: (1) scope of disclosure (regular reporting of asset quality and transaction performance in investor reports, initial disclosure consistent with the RTS for the CRA3 Regulation), and (2) requirement of distributed tranches to be listed on a regulated exchange or admitted to trading on another organized venue.

\section{Additional Criteria for SME Securitization}

4. Definition of asset class: (1) obligors meet the European Commission's definition of SMEs; (2) conform to the terms and conditions of European Investment Bank -intermediated lending; and (3) type of SME lending defined as financing leases, credit lines/guarantees, promissory notes, debentures, concessionary loans, and other loans that serve a real investment purpose.

5. Portfolio characteristics: (1) sufficient diversification/granularity and no credit-specific differences to originator's overall loan portfolio; (2) limits on the aggregate outstanding balance of securitized assets without scheduled principal payments; and (3) creditor track record of at least one annual reporting period. 


\section{The regulatory endorsement of the HQS concept should not engender investor} complacency. Capital charges for investment in HQS should require sufficient nuance (beyond the current use of rating categories and tranche thickness as quality criteria) reflecting all relevant structural features through a standardized classification of individual risk dimensions. ${ }^{20}$ Recognizing different degrees of risk within HQS - through standardized classifications at the level of duration risk, prepayment risk, asset correlation/concentration risk, collateral fungibility, and track record of credit performance-would be necessary. ${ }^{21}$ This would encourage greater due diligence by investors (in lieu of relying exclusively on the aggregate risk label or assessments by credit rating agencies), enhance the risk assessment of investment based on the compliance of HQS structures with more granular risk dimensions, and mitigate the risk of creating a fragmented market with significant pricing discontinuities (Segoviano and others 2015).

23. Against the background of an emerging consensus on the concept of HQS (Annex II), important implementation issues would need to be addressed. The European Commission's intended draft legislation for the implementation of HQS within the existing regulatory framework would define high-level principles for the operationalization of HQS, to be subsequently specified in detail by Regulatory Technical Standards (RTS). These would include the accountability and governance framework for the designation of HQS and the due diligence required by market participants and supervisors. This could be modeled after the European Commission's implementation process of uniform risk retention requirements for securitization in 2011.

\section{B. Strengthening the Infrastructure for SME Securitization}

\section{Harmonized reporting requirements and improved access to credit data would} facilitate SME securitization. Standardized reporting on the default frequency of SMEs and the differences between SME loan portfolios in terms of size, business activity, and geographic location would lower the cost of SME securitization, facilitate credit risk assessment by investors, and ensure the comparability of SME loan performance within Europe. This would provide the empirical basis for differentiating between securitization transactions of different quality and facilitate the development of cross-border securitization within a more integrated and enhanced capital market.

- Collecting SME credit information based on the taxonomy of the Eurosystem's collateral framework. The ECB's loan-level data initiative has established requirements for transparency and standardization as necessary preconditions for the acceptance of ABS-including SME ABS -as collateral for Eurosystem refinancing operations. The detailed information on borrower and loan characteristics, which is collected by the European Datawarehouse (EDW), can be used by current and potential investors to carry out their own credit analysis, and thereby help address

\footnotetext{
${ }^{20}$ This also includes the recognition of risk mitigation mechanisms embedded in asset structures.

${ }^{21}$ Some of the existing proposals for HQS, such as the distinction between senior and non-senior Type 1 (HQS) transactions held by insurers (Solvency II) and the current consultation by EBA (2014) on HQS for European banks, already include a discussion of relevant individual risk factors, which have yet to be fully reflected in the regulatory treatment of securitization.
} 
information asymmetries. The Single Supervisory Mechanism (SSM) could adapt the same reporting requirements for supervisory purposes. This could be facilitated by expanding the scope of data collection by the EDW to include also non-securitized loans (for pricing and benchmarking) to facilitate more comprehensive and robust price discovery. Better information could also provide the basis for greater flexibility in calibrating regulatory capital requirements for securitized SME loans.

- Making SME credit information available to investors. The role of the SSM in generating standardized and continuous credit quality information on SME lending would ideally be paired with the development and harmonization of credit registries and reliable financial reporting by SMEs. As more comparable and harmonized prudential information about SMEs becomes available, creditor access could be enhanced further by the development of an EU-wide credit register. This could build on the ongoing efforts by the ECB toward the gradual formation of a credit register for countries in the banking union (ECB 2014b). Consideration could also be given to developing a private-sector European credit bureau.

\section{A functional convergence of debt enforcement regimes across EU countries would} facilitate collateral access and further support cross-border investment. Many countries have undertaken reforms to speed up debt restructuring during the crisis; however, considerable variation and weaknesses in national enforcement and insolvency regimes continue to raise the legal cost of debt restructuring and prevent the timely resolution of the large debt overhang (Erbenova, Lui, Saxegaard 2011). Full harmonization of enforcement and insolvency regimes is likely to be politically difficult to achieve. The current European Insolvency Regulation assumes that countries have different regimes, but creates mechanisms for the mutual recognition of insolvency processes and cooperation among courts and insolvency representatives in different member states. And the European Commission has taken a step toward establishing common general principles for EU countries through nonbinding recommendations for pre-insolvency regimes and out-of-court restructuring ${ }^{22}$ to support timely rehabilitation of distressed borrowers (European Commission 2014h). Such functional convergence of enforcement and insolvency regimes across EU countries would greatly facilitate the move toward an EU Capital Markets Union (European Commission 2015a).

\section{A mutual issuance platform, either at the national or euro area-wide level, would allow} SMEs to issue securitization transactions without bank intermediation. Such an issuance

\footnotetext{
22 The establishment of special procedures, outside the formal bankruptcy framework, may expedite debt restructuring. Out-of-court approaches have been established in a number of EU countries, and create a framework for negotiations between creditors and debtors. They should be backed by credible court-supervised processes for seizure of assets, foreclosure, liquidation, and reorganization. Without the threat of court-imposed loss, there is not enough incentive for debtors to agree to asset sales, equity dilution, and/or reduction in management control that may be part of a fair restructuring deal. SMEs may require a streamlined, cost-effective, flexible, and possibly more mediated approach that falls in between corporate and personal standards, as frequently the line between assets and income of the enterprise and the owner's household is blurred, and debt restructuring for viable SMEs may require that both be included. See Bergthaler and others (2015) for a more extensive discussion of possible reforms to insolvency regimes for SMEs. See also Barkbu, Jassaud, and Kang (2013).
} 
platform could also be used for other financial instruments, such as mini-bonds, and could build on efforts to achieve greater harmonization of SME funding in line with recent recommendations by European Commission's High Level Expert Group on SME and Infrastructure Financing (2013b) and the Communication on Long-term Financing of the European Economy (2014j). ${ }^{23}$ Also, forms of nonbank intermediated securitization (such as trade receivables via asset-backed commercial paper (ABCP) facilities) and equity finance (Wehinger and Nassr 2015) should be explored in areas where structural and legal impediments to asset securitization are too high and cannot be overcome in the near term.

\section{Finally, consideration should be given to widening the range of eligible asset classes} for covered bonds to include SME loans. Given the pervasive use of covered bonds (or structured dual recourse instruments) by banks in some countries, this would further encourage the use of standardized and more efficient origination and loan pricing processes and enhance the possible economic impact of improved credit quality information about SMEs (Jobst, Kiff, and Surti 2011; Jobst 2015).

\section{Providing Targeted Official-Sector Support}

\section{Greater and more targeted official-sector support will be needed to restart the SME} securitization markets. Integrating current EU initiatives for SME finance, enhancing the catalytic role of certain institutions, introducing greater differentiation in the treatment of securitization transactions within the collateral framework of the Eurosystem, and widening the existing asset purchase program would foster information disclosure, provide a positive signaling effect to investors, and boost issuance. Progress in these directions would encourage developing securitization structures that facilitate the transfer of SME lending risks from banks to capital markets.

\section{Reconciling and integrating existing European initiatives would exploit operational} synergies and achieve greater scale for new SME securitization. Current programs-such as the COSME securitization option or the EIB/EIF Credit Enhancement-provide support to SME securitization through guarantees. Other programs - such as the EU SME Loan Initiative and the Juncker investment plan-combine contributions from the EIB Group with EU funds to provide guarantees for securitization instruments backed by SME loans. While these programs would be scalable, they remain too small in size to have a broad impact on the European SME securitization market. For example, the securitization option under the EU SME Loan Initiative could generate about $€ 28-35$ billion in new SME lending if all EU member countries participated with the maximum amount (€13.4 billion), compared to a market for SME loans that is currently around $€ 1.4$ trillion in outstanding loans. With Spain's participation of $€ 0.8$ billion, the expected impact would be only

\footnotetext{
${ }^{23}$ Mini-bonds were introduced in 2012 as part of Italy's SME Capital Market Plan to facilitate unlisted firms' access to capital markets. Mini-bonds have been mostly used by larger SMEs. The issuance of mini-bonds has been encouraged by tax exemptions for both issuers and investors. Note that the EIF is currently working on support mechanisms concerning debt funds (including mini-bonds) for SMEs (Kraemer-Eis and others 2014b).
} 
about $€ 3.2$ billion. Combining existing guarantee schemes with programs that use EU funds and setting up a one-stop shop at the EIB would make it easier for originators/issuers and investors to obtain information and apply for support, enhancing the scope and effectiveness of existing officialsector support.

\section{While confidence in HQS is being built up, European development institutions should} facilitate market activity and encourage genuine risk-sharing through securitization. Various European institutions could expand their current/planned support by acting as guarantors or strategic investors in more cost-efficient transactions with all (or most tranches) distributed to nonbank investors implying genuine diversification of credit risk (Box 2). This could be achieved, for example, by enhancing their capacity to provide official-sector guarantees ("wrappers") to mezzanine tranches (based on the existing EIF Credit Enhancement Program, see Table 1), which would reduce the cost of subordination and provide capital relief for the originator as those tranches become (more) marketable. ${ }^{24}$ Direct co-investment in senior tranches (as strategic investor) would boost their ratings and provide economic incentives to decrease the amount of subordination (and the tendency to retain tranches for refinancing purposes only), making asset structures more efficient. ${ }^{25}$ Overall, public sector support for asset structures would provide an important signaling effect to investors; thereby enhancing secondary market liquidity for guaranteed tranches and reducing the credit risk of current and future asset purchases by the Eurosystem (Box 5). ${ }^{26}$ The potential for long-term distortionary effects should be combated by making any supply-side support risk-sensitive and time-bound.

\section{A more nuanced treatment of HQS within the Eurosystem collateral framework would} foster incentives for market-based securitization. Given that a large share of outstanding securitization transactions is already held as collateral by the Eurosystem, the recognition of HQS for refinancing purposes remains relevant for market development in the near term. ${ }^{27}$ For any tranche of a securitization transaction to be eligible as collateral for refinancing purposes with the Eurosystem, the entire underlying asset structure should satisfy all relevant HQS criteria (Box 4). It should also meet the current loan level disclosure standards of the ECB, and satisfy some extra requirements (see bullet points below). This would support the development of more transparent and standardized transactions in which most tranches are distributed, as opposed to transactions

\footnotetext{
${ }^{24}$ Note that the issuing bank obtains capital relief from securitization only if it can place 50 percent or more of investment-grade "mezzanine" tranches (rated from AA to BBB-) of a securitization transaction with third-party investors (in addition to the top-rated senior tranche).

${ }^{25}$ The price of such guarantees-assuming fair value pricing - would be expected to fall over time, as markets deepen and confidence in the characteristics of HQS grows.

${ }^{26}$ Such purchases could include transactions backed by legacy assets or new lending and would focus on increasing the price of senior tranches so subordinate (mezzanine) tranches can be placed at prices that can fund lending at lower interest rates. Otherwise new lending might be constrained by the lack of demand if rates remain too high for borrowers to generate positive returns from investment.

${ }^{27}$ The treatment of securitization in the collateral framework is likely to diminish in importance as the investor base becomes more diverse (and bank funding becomes less dependent on the credit operations of the Eurosystem).
} 
structured primarily to meet eligibility requirements for central bank funding, in which sizeable retained tranches support a relatively small senior tranche used as collateral. ${ }^{28} \mathrm{All}$ tranches above the lesser of the applicable minimum retention requirement and the most junior tranche would need to be assessed by two or more external credit assessment institutions (ECAIs) and comply with the following criteria: ${ }^{29}$

- Ensure the marketability of the entire asset structure. The most senior tranche of the transaction must receive the highest possible external credit rating by at least two ECAIs. The amount of structural subordination supporting the senior tranche should receive an external credit assessment consistent with the minimum credit quality for collateral assets accepted by the Eurosystem. $^{30,31}$

- Minimize tranche retention above the regulatory minimum to increase risk transfer. Any amount of voluntary tranche retention in excess of the greater of the minimum retention requirement (required under the CRR) and the notional amount of the most junior tranche would need to be equal to or less than the notional amount transferred or sold to third-party investors, net of the senior tranche.

- Require comprehensive disclosure at issuance and periodic performance reporting. Standardized reporting by issuers on both securitized and non-securitized assets-including their nonperformance-would facilitate price discovery, enhance consistency of risk control measures relative to credit claims as Eurosystem collateral, and enhance risk monitoring.

\section{Valuation haircuts should differ according to the scope of disclosure requirements. ${ }^{32}$}

This could be achieved by drawing upon the information in the loan-level data reporting from the EDW, and would help balance risk management requirements against the frequent lack of reliable market prices for some tranches/transactions. ${ }^{33}$ Better information on credit risk parameters would

\footnotetext{
${ }^{28}$ Widening the scope of the HQS concept beyond the senior tranche to the quality of the securitization process would also avoid potential overlap of credit risk assessment with existing regulatory capital standards at the tranche level.

${ }^{29}$ These criteria exceed the rating and subordination requirements defined in the HQS criteria proposed in Annex II in conjunction with EBA (2014) and BCBS/IOSCO (2014)

${ }^{30}$ This refers to the notional amount of one or more tranches above the most junior tranche (which covers expected losses) below the most senior tranche of the transaction.

${ }^{31}$ The threshold is currently set to the lowest investment grade rating of BBB- (or credit quality step [CQS] ranking of three (3) under the temporary collateral framework).

${ }^{32}$ Securitization transactions carry greater market risk due to lower liquidity and thus should be subject to higher valuation haircuts for refinancing with the Eurosystem. However, under the current "haircut schedule" (ECB 2013b), securitization transactions are generally assigned the lowest "haircut category," which provides no detailed differentiation other than a broad ratings-based distinction between high investment grade (AAA to $A-$ ) or low investment grade (BBB + to $\mathrm{BBB}-)$ determining the initial margin.

${ }^{33}$ Changes in the composition and asset quality of the reference portfolio underlying securitization transactions are reported to the EDW monthly; this information could be used for valuation purposes if the overcollateralization of posted transactions is deemed sufficient to reduce the daily valuation of collateral to a lower frequency. Expanding
}

(continued) 
warrant exploring options for (and greater flexibility in the calibration of) more differentiated valuation haircuts for collateral in Eurosystem refinancing operations. Haircuts could be set in a manner that is consistent across asset types and funding instruments-for example securitization transactions, covered bonds, secured whole loan portfolio funding, and whole loan sales, among others. Finally, better information could also provide the basis for greater flexibility in setting valuation haircuts based on loss given default (LGDs) for non-securitized SME loans.

\section{Box 5. The European Central Bank's Asset-Backed Securities Purchase Program}

The scale and scope of the European Central Bank's (ECB's) private asset purchases of asset-backed securities $(A B S)$ represents an important aspect of official sector support for SME securitization.

In late 2014, the ECB introduced its private asset purchase program of securitization transactions and covered bonds (with a policy focus on easing credit conditions for SMEs). As part of this program, the ECB started purchasing ABS on November 21, 2014, one month after the implementation of the third covered bonds purchase program (CBPP3). These purchases are aimed at further strengthening the ECB's accommodative monetary stance, on account of the proximity to the zero interest rate bound. The ECB $(2014 d)^{34}$ clarified that eligible ABS would be purchased in both primary and secondary markets over a period of at least two years, subject to detailed eligibility criteria that exceed those set out in the General Documentation for refinancing operations with the Eurosystem, with some derogations for Greek/Cypriot issuers subject to additional requirements. As of the May 1, 2015, reference date some $€ 5.8$ billion of ABS had been purchased under ABSPP, after five months of purchases at an average weekly run-rate of $€ 300$ million. Assuming the Asset-Backed Securities Purchase Program (ABSPP) continues at the same pace, purchases would lead to an annual volume of about $€ 13$ billion (or about 0.6 percent of the ECB's current balance sheet). ${ }^{35}$

\section{CONCLUSION}

\section{The further development of securitization could help mitigate structural constraints} on credit supply to smaller firms in Europe. Given the lack of diversified funding markets, with only the largest nonfinancial firms being able to directly access capital markets, credit supply to SMEs is heavily influenced by bank lending. The dominance of intermediated funding has constrained the recovery of credit supply in the wake of the recent financial crisis. Developing alternative funding sources for SMEs, such as SME securitization, would ensure lending to viable

\footnotetext{
the mandate of the EDW to include data collection of non-securitized loans (for pricing) and credit claims used for repos with the Eurosystem could also be considered.

${ }^{34}$ Decision ECB/2014/45 supplements Technical Annex 1 (on ABSPP), which was released along with the initial announcement in early October.

${ }^{35}$ After considering the stipulated limit on maximum purchases of 70 percent per transaction, the ECB eligible ABS "universe" is about $€ 485$ billion-compared to just $€ 975$ billion in covered bonds, which would fall to around $€ 700$ billion if smaller transactions ( $<€ 500$ million) are excluded (as in previous purchasing programs of covered bonds).
} 
smaller firms during times of banking sector difficulties, and, thus, enhance the resilience of the economy. Restarting securitization could also help overcome the adverse effects of financial fragmentation, improve the allocation and pricing of liquidity, support cross-border investment, and enhance the transmission of monetary policy.

\section{Official sector support would be required, at least initially, to promote securitization} as a viable market-based source of long-term finance for SMEs. Elements of this support could include: (1) raising the capacity of European development institutions to support SME finance, (2) amending the Eurosystem collateral framework, and (3) incorporating any changes to collateral eligibility in the current private asset purchase program. These measures should be combined with greater regulatory differentiation of HQS transactions and structural reforms to enhance the attractiveness of SME finance for non-bank investors. 


\section{ANNEX I. REGULATORY CAPITAL CHARGES FOR CREDIT EXPOSURES AND SECURITIZATION ${ }^{1}$}

\begin{tabular}{|c|c|c|c|c|c|c|c|}
\hline \multicolumn{8}{|l|}{$\begin{array}{l}\text { Table A1. Overview Comparison of Regulatory Capital Char } \\
\text { Investment in Securitization } \\
\text { (Percent) }\end{array}$} \\
\hline \multirow[b]{2}{*}{ Credit rating } & \multicolumn{4}{|c|}{ Investment Grade } & \multicolumn{3}{|c|}{ Non-Investment Grade } \\
\hline & AAA & AA & $\mathrm{A}$ & BBB & $\mathrm{BB}$ & $\mathrm{B}$ & Below B \\
\hline \multicolumn{8}{|l|}{ Banking } \\
\hline \multicolumn{8}{|l|}{ Credit exposures } \\
\hline Non-financial corporates (non-SME) & 1.6 & 1.6 & 4.0 & 8.0 & 8.0 & 12.0 & 12.0 \\
\hline SME loans & 4.6 & 4.6 & 4.6 & 4.6 & 4.6 & 4.6 & 4.6 \\
\hline \multicolumn{8}{|l|}{ Securitization $^{1}$} \\
\hline Any credit exposure, senior tranche, 5 -year maturity ${ }^{2}$ & 1.6 & 3.2 & 5.2 & 8.4 & 14.4 & 27.2 & $\begin{array}{c}40.4 / 10 \\
0\end{array}$ \\
\hline Any credit exposure, non-senior tranche, 5-year maturity & 5.6 & 9.6 & 14.4 & 24.8 & 60.8 & 84.0 & 100 \\
\hline \multicolumn{8}{|l|}{ Insurance } \\
\hline \multicolumn{8}{|c|}{ Solvency II Directive (EIOPA, 2014; European Commission, 2014d) ${ }^{3}$} \\
\hline \multicolumn{8}{|l|}{ Credit exposures } \\
\hline Nonfinancial corporates (incl. SME loans), 5-year duration & 4.5 & 5.5 & 7.0 & 12.5 & 22.5 & 37.5 & 37.5 \\
\hline \multicolumn{8}{|l|}{ Securitization } \\
\hline Type 1 (defined asset classes), senior/first-pay tranche only, 5 -year duration ${ }^{4}$ & 10.5 & 15.0 & 15.0 & 15.0 & n.a. & n.a. & n.a. \\
\hline Type 2 (defined asset classes), non-senior/first-pay tranche only, 5 -year duration ${ }^{45}$ & 62.5 & 67.0 & 83.0 & 98.5 & 100 & 100 & 100 \\
\hline \multicolumn{8}{|c|}{ 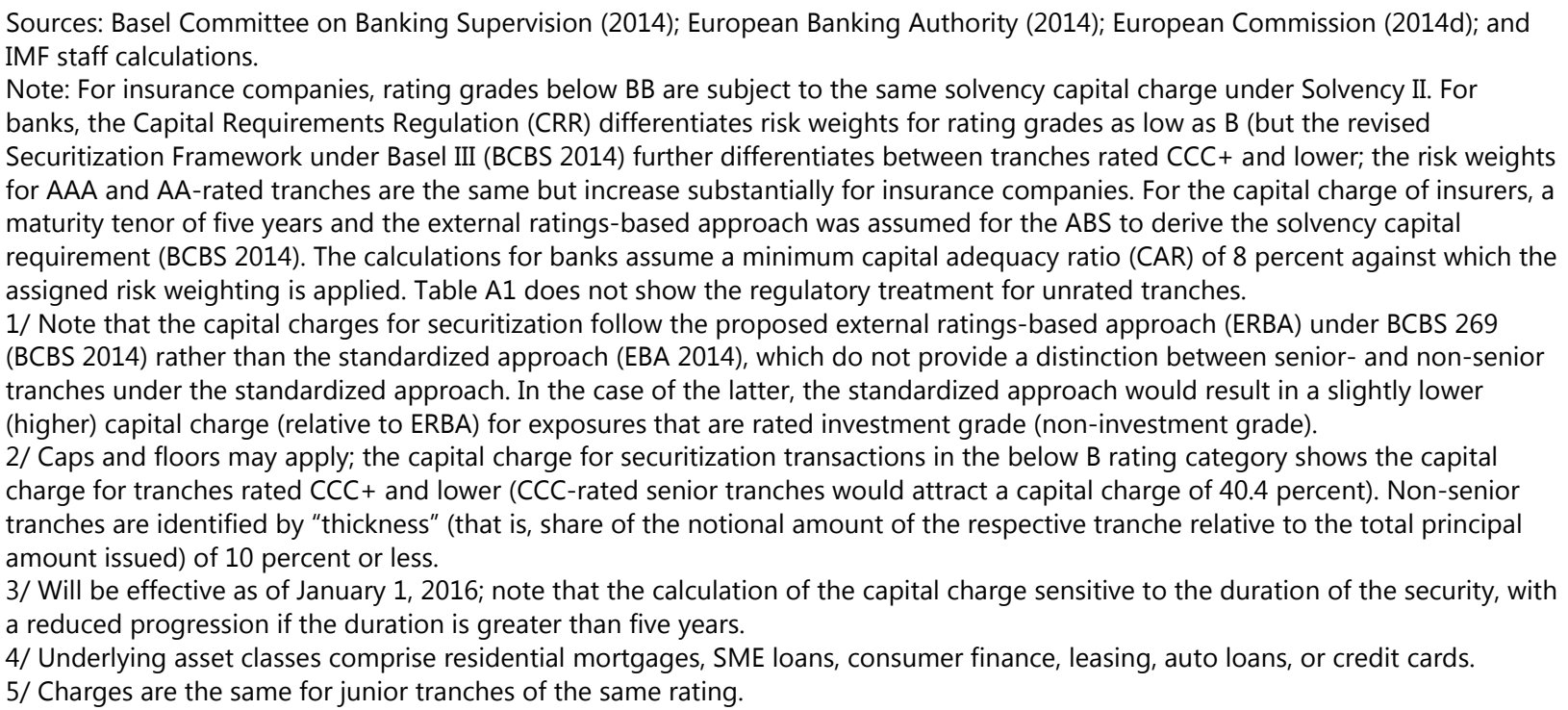 } \\
\hline
\end{tabular}

\footnotetext{
${ }^{1}$ This Annex was written by Andreas A. Jobst.
} 


\section{References}

Aiyar, Shekhar, Bergljot Barkbu, and Andreas A. Jobst. 2014. "Seminar on SME Financing: Europe Needs to Revitalize Finance for Small and Medium Enterprises." IMF Survey Magazine (November). http://www.imf.org/external/pubs/ft/survey/so/2014/CAR110514A.htm.

Aiyar, Shekhar, Charles W., Calomiris, and Tomasz Wieladek. 2014. "How Does Credit Supply Respond to Monetary Policy and Bank Minimum Capital Requirements?" Bank of England Working Paper 508, Bank of England, London.

Al-Eyd, Ali, Barkbu, Bergljot, Berkmen, S. Pelin, John Bluedorn, Andreas Jobst, A., and Alexander Tieman, 2014. "Capital Market Development: SME Financing in the Euro Area." Euro Area Policies: Selected Issues, IMF Country Report 14/199, International Monetary Fund, Washington. http://www.imf.org/external/pubs/ft/scr/2014/cr14199.pdf.

Bank of England. 2014. "Extract from the Red Book: The Bank's Current Operations in the Sterling Money Markets." London.

http://www.bankofengland.co.uk/markets/Documents/money/publications/redbookcollater al.pdf.

— 2010. "Information Transparency for Asset-Backed Securities." Bank of England Market Notice, London.

http://www.bankofengland.co.uk/markets/Documents/marketnotice100719a.pdf.

— Roadblocks and How to Deal with Them." European Central Bank, Frankfurt am Main. http://www.ecb.europa.eu/pub/pdf/other/ecbboe case better functioning securitization marketen.pdf.

2014b, "The Case for a Better Functioning Securitization Market in the European Union." European Central Bank, Frankfurt am Main. http://www.ecb.europa.eu/pub/pdf/other/ecbboe case better functioning securitization marketen.pdf.

Barkbu, Bergljot, Nadège Jassaud, and Kenneth Kang. 2013. "Strategy for Fostering A Market for Distressed Debt in Italy." IMF Country Report 13/299, International Monetary Fund, Washington.

Basel Committee on Banking Supervision (BCBS). 2011. "Basel III: A Global Regulatory Framework for More Resilient Banks and Banking Systems." Bank for International Settlements, Basel. http://www.bis.org/publ/bcbs189.pdf.

2014. "Revisions to the Securitization Framework." Bank for International Settlements, Basel. http://www.bis.org/bcbs/publ/d303.pdf.

—, and International Organization of Securities Commissions (IOSCO). 2014. "Simple, Transparent and Comparable Securitizations." Consultative Document, Joint Task Force on Securitisation Markets, Bank for International Settlements, Basel. http://www.bis.org/bcbs/publ/d304.pdf. 
Bergthaler, Wolfgang, Kenneth Kang, Yan Liu, and Dermot Monaghan. 2015. "Tackling SME Problem Loans in Europe." Staff Discussion Note 15/04, International Monetary Fund, Washington. http://www.imf.org/external/pubs/ft/sdn/2015/sdn1504.pdf.

Bernanke, Ben. 2007. "The Financial Accelerator and the Credit Channel." Speech at The Credit Channel of Monetary Policy in the Twenty-first Century Conference, Federal Reserve Bank of Atlanta, Atlanta, June 15.

Covered Bond Label Foundation (CBLF). 2014. "Covered Bond Label Convention 2015", November 14. https://www.coveredbondlabel.com/pdf/Covered Bond Label Convention 2015.pdf

Darvas, Zsolt. 2013. "Banking System Soundness is the Key to More SME Financing." Policy Department, European Commission Brussels.

Disyatat, Piti. 2011. "The Bank Lending Channel Revisited." Journal of Money, Credit and Banking. 43 (4): 711-34.

Erbenova, Michaela, Yan Liu, and Magnus Saxegaard. 2011. "Corporate and Household Debt Distress in Latvia: Strengthening the Incentives for Market-Based Approach to Debt Resolution." IMF Working Paper 11/85, International Monetary Fund, Washington.

European Banking Authority (EBA). 2014. "EBA Discussion Paper on Simple, Standard and Transparent Securitizations." London. https://www.eba.europa.eu/documents/10180/846157/EBA-DP-2014$\underline{02+\text { Discussion+Paper+on+simple+standard +and +transparent+securitizations.pdf. }}$.

European Central Bank (ECB). 2014a. "Deleveraging Patterns in the Euro Area Corporate Sector." ECB Monthly Bulletin (February).

2014b. "Organization of Preparatory Measures for the Collection of Granular Credit Data by the European System of Central Banks." Frankfurt am Main. https://www.ecb.europa.eu/ecb/legal/pdf/en dec 2014 6.pdf. 2014c, "Capital Markets Union - the "Why" and the "How," Speech by Yves Mersch, Brussels, October 22, at http://www.ecb.europa.eu/press/key/date/2014/html/sp141022 1.en.html 2014c. "Implementation of the Asset-Backed Securities Purchase Program." Frankfurt am Main. https://www.ecb.europa.eu/ecb/legal/pdf/en ecb 201445 f sign.pdf.

. 2013a. "ABS Loan-level Initiative," Frankfurt am Main. https://www.ecb.europa.eu/paym/coll/loanlevel/html/index.en.html.

2013b. "Decision on Additional Measures Relating to Eurosystem Refinancing Operations and Eligibility of Collateral." Frankfurt am Main. http://www.ecb.europa.eu/ecb/legal/pdf/l 30120131112en00060012.pdf.

. 2012. "Amendment of Guideline ECB/2011/14 on Monetary Policy Instruments and Procedures of the Eurosystem." Frankfurt am Main. http://www.ecb.int/ecb/legal/pdf/en ecb 201225 f sign.pdf. 
2010. "ECB Introduces ABS Loan-by-Loan Information Requirements in the Eurosystem Collateral Framework." Frankfurt am Main.

https://www.ecb.europa.eu/press/pr/date/2010/html/pr101216.en.html.

European Commission. 2002. "Directive 2002/83 of the European Parliament and the Council

Concerning Life Assurance." Brussels. http://eur-lex.europa.eu/legalcontent/EN/TXT/PDF/?uri=CELEX:32002L0083\&from=EN.

. 2013a. "A Recovery on the Horizon?," Annual Report on European SMEs 2012/2013, Brussels. http://ec.europa.eu/enterprise/policies/sme/facts-figures-analysis/performancereview/files/sme-pr-final-annual-report 2012-13 en.pdf.

2013b. "Finance for Growth," High Level Expert Group on SME and Infrastructure Financing, Brussels. http://europa.eu/efc/working groups/hleg report 2013.pdf.

. 2014a. "A Partial and Fragile Recovery_Annual Report on European SMEs 2013/2014."

Brussels. http://ec.europa.eu/enterprise/policies/sme/facts-figures-analysis/performancereview/files/supporting-documents/2014/annual-report-smes-2014 en.pdf.

. 2014b. "Commission Delegated Regulation to Supplement Regulation (EU) 575/2013 with Regard to Liquidity Coverage Requirement for Credit Institutions." Brussels. http://ec.europa.eu/internal market/bank/docs/regcapital/acts/delegated/141010 delegate d-act-liquidity-coverage en.pdf.

2014c. "Commission Delegated Regulation Amending Regulation (EU) No 575/2013 of the European Parliament and of the Council with Regard to the Leverage Ratio." Brussels. http://ec.europa.eu/internal market/bank/docs/regcapital/acts/delegated/141010 delegate $\underline{\mathrm{d} \text {-act-leverage-ratio en.pdf. }}$

. 2014d. "Commission Delegated Regulation Supplementing Directive 2009/138/EC of the European Parliament and of the Council on the Taking-up and Pursuit of the Business of Insurance and Reinsurance (Solvency II)." Brussels.

http://ec.europa.eu/internal market/insurance/docs/solvency/solvency2/delegated/141010delegated-act-solvency-2 en.pdf.

2014e. "Proposal for a Directive of the European Parliament and the Council on the Activities and Supervision of Institutions for Occupational Retirement Provision." Brussels. http://eur-lex.europa.eu/legal-content/EN/TXT/?uri=CELEX:52014PC0167.

. 2014f. "Ex-Ante Assessment of the EU SME Initiative." http://eur-lex.europa.eu/legalcontent/EN/TXT/?uri=CELEX:52014PC0167. Brussels.

2014g. "An Investment Plan for Europe," Communication from the Commission to the European Parliament, the Council, the European Central Bank, the European Economic and Social Committee, the Committee of the Regions and the European Investment. Brussels. http://ec.europa.eu/priorities/jobs-growth-investment/plan/docs/an-investment-plan-foreurope com 2014903 en.pdf 
2014h. "Commission Recommendation on a New Approach to Business Failure and Insolvency." Brussels. http://ec.europa.eu/justice/civil/files/c 20141500 en.pdf.

. 2014i. "Study on a New Approach to Business Failure and Insolvency - Comparative Legal Analysis of the Member States' Relevant Provisions and Practices: Annex 2 (Part 1: Confidential Proceedings)." Brussels. http://ec.europa.eu/justice/civil/files/insol europe report 2014 annexes en.pdf.

. 2014j. "Communication from the Commission to the European Parliament and the Council on Long-Term Financing of the European Economy." Brussels. http://ec.europa.eu/internal market/finances/docs/financing-growth/long-term/140327communication en.pdf.

_ 2015a. "Building a Capital Markets Union." Brussels.

http://ec.europa.eu/finance/consultations/2015/capital-markets-union/docs/greenpaper en.pdf.

. 2015b. "An EU Framework for Simple, Transparent and Standardised Securitization." Brussels. http://ec.europa.eu/finance/consultations/2015/securitisation/index en.htm.

. 2015c. "Proposal for a Regulation of the European Parliament and of the Council on the European Fund for Strategic Investments and Amending." Strasbourg. http://ec.europa.eu/priorities/jobs-growthinvestment/plan/docs/proposal regulation efsi en.pdf

European Insurance and Occupational Pensions Authority (EIOPA). 2013. "Technical Report on Standard Formula Design and Calibration for Certain Long-Term Investments." Frankfurt am Main. https://eiopa.europa.eu/consultations/consultation-papers/2013-closedconsultations/april-2013/discussion-paper-on-standard-formula-design-and-calibrationfor-certain-long-term-investments/index.html.

European Investment Bank (EIB). 2014. "COSME Securitization Option Term Sheet." Luxembourg. http://www.eif.org/what we do/guarantees/single eu debt instrument/cosme-loan-facilitygrowth/index.htm.

European Private Equity and Venture Capital Association (EVCA). 2014. "European Private Equity Activity, 2007-2013." Brussels. http://www.evca.eu/media/165475/yearbook-2014-europecountry-tables-final.xlsx.

European Securities and Markets Authority (ESMA). 2014. "Draft Regulatory Technical Standards under the CRA3 Regulation." Paris. http://www.esma.europa.eu/content/Draft-RegulatoryTechnical-Standards-under-CRA3-Regulation.

Franke, Guenther, and Jan Pieter Krahnen. 2008. "The Future of Securitization." Center for Financial Studies Working Paper 2008/31, Center for Financial Studies, Frankfurt am Main. http://www.ifk-cfs.de/fileadmin/downloads/publications/wp/08 31.pdf. 
Galizia, Federico, and Giovanni Gentili. 2014. "Management and Transfer Pricing of Collateral." In The Handbook of ALM in Banking: Interest Rates, Liquidity and the Balance Sheet, edited by A. Bohn and M. Elkenbracht-Huizing. London: RISK Books.

Giovannini, Alberto, Colin Mayer, Stefano Micossi, Carmine Di Noia, Marco Onado, Marco Pagano, and Andrea Polo. 2015. "Restarting European Long-Term Investment Finance." A Green Paper Discussion Document, Centre for Economic Policy Research, London. http://reltif.cepr.org/sites/default/files/RELTIF Green\%20Paper.pdf.

Hopkin, Richard, Anna Bak, and Sidika Ulker, 2014, "High-Quality Securitization for Europe-The Market at a Crossroads." Association for Financial Markets in Europe, London. http://www.afme.eu/WorkArea/DownloadAsset.aspx?id=10823.

International Monetary Fund (IMF). 2009. "Chapter II: Restarting Securitization Markets: Policy Proposals and Pitfalls." In Global Financial Stability Report, Washington, October. http://www.imf.org/External/Pubs/FT/GFSR/2009/02/pdf/chap2.pdf.

2011. "Germany: Technical Note on the Future of German Mortgage-Backed Covered Bond (Pfandbrief) and Securitization Markets." Country Report 11/369, Washington. http://www.imf.org/external/pubs/ft/scr/2011/cr11369.pdf.

Jobst, Andreas A. 2006. "Asset Securitization as a Risk Management and Funding Tool: What Small Firms Need to Know." Managerial Finance 32 (9): 731-60. 2008. "What is Securitization?" Finance and Development 47 (3): 48. 2009. "Islamic Securitization-An Ethical Remedy to Incentive Problems?" International Journal of Monetary Economics and Finance 2 (3/4): 348-65.

Mangal Goswami, and Xin Long. 2009. "An Investigation of Some Macro-Financial Linkages of Securitization." IMF Working Paper 9/26. International Monetary Fund, Washington. http://www.imf.org/external/pubs/ft/wp/2009/wp0926.pdf.

and John Kiff. 2011. "Capital Markets-based Funding in German Banking-Securitization and Covered Bonds." Zeitschrift für das gesamte Kreditwesen 64 (19): 1004-07.

John Kiff, and Jay Surti, 2011. "Covered Bonds and Asset Encumbrance." In Fact Book 2011. Brussels: European Covered Bond Council.

2015. "Monetary Policy and Capital Market Integration in the Euro Area: What is the Role of Covered Bonds?" Journal of Structured Finance. 20 (4). 107-19.

Kraemer-Eis, Helmut, and George Passaris. 2015. "SME Securitization in Europe." Journal of Structured Finance 20 (4): 97-106.

Kraemer-Eis, Helmut, Frank Lang, and Salome Gvetadze. 2014a. "European Small Business Finance Outlook." EIF Working Paper 2014/24, European Investment Fund, Luxembourg. http://www.eif.org/news centre/publications/eif wp 24.pdf. 
Kraemer-Eis, Helmut, Francesco Battazzi, Remi Charrier, Marco, Natoli, and Matteo Squilloni. 2014b. "Institutional Non-Bank Lending the Role of Debt Funds." EIF Working Paper 2014/25, European Investment Fund, Luxembourg. http://www.eif.org/news centre/publications/eif wp 25.pdf.

Lam, W. Raphael, and Jongsoon Shin. 2012. "What Role Can Financial Policies Play in Revitalizing SMEs in Japan?" IMF Working Paper 12/291, International Monetary Fund, Washington. https://www.imf.org/external/pubs/ft/wp/2012/wp12291.pdf.

Segoviano, Miguel, Bradley Jones, Peter Lindner, and Johannes Blankenheim. 2015. "Securitization: Lessons Learned and the Road Ahead." Staff Discussion Note 15/01, International Monetary Fund, Washington. http://www.imf.org/external/pubs/ft/sdn/2015/sdn1501.pdf.

"Securitization: Lessons Learned and the Road Ahead." IMF Working Paper 13/255, International Monetary Fund, Washington. http://www.imf.org/external/pubs/ft/wp/2013/wp13255.pdf.

Shin, Hyung Song. 2009. "Securitization and Financial Stability." The Economic Journal 119 (536): 309-32.

Van den Heuvel, Skander J. 2007. "The Bank Capital Channel of Monetary Policy." Unpublished, Department of Finance, The Wharton School, University of Pennsylvania.

Wehinger, Gert, and Iota Nassr. 2015. "SME Debt Financing Beyond Bank Lending: The Role of Securitization, Bonds and Private Placements." Organisation for Economic Co-operation and Development, Paris.

World Bank. 2014. Doing Business Survey 2014-Understanding Regulations for Small and MediumSize Enterprises. (Washington: World Bank Group). 